\title{
Surface-Induced Deprotonation of Thiol Ligands Impacts Optical Response of CdS Quantum Dots
}

Levi Lystrom, ${ }^{\dagger}$ Alyssa Roberts, ${ }^{\dagger}$ Naveen Dandu, ${ }^{+}$and Svetlana Kilina ${ }^{\dagger *}$

${ }^{\dagger}$ Chemistry and Biochemistry, North Dakota State University, Fargo, North Dakota 58108, U.S.

${ }^{+}$Argonne National Laboratory, Lemont, Illinois 60439, U.S.

Corresponding Author* skilina@gmail.com

Table S1: Natural bond orbital (NBO) analysis representing the charge (in e) on several selected atoms of the fully passivated $(\mathrm{CdS})_{33}$ QD with 20 methylamines and one thiol, or thiolate, or thiolate/H calculated in acetonitrile. The values calculated in propylamine solvent are shown in parentheses. The values highlighted in bold font represent the charge on the surface sulfur interacting with the proton.

\begin{tabular}{|c|c|c|c|c|c|}
\hline & & Cd & $S_{Q D}$ & $S_{L}$ & $\mathbf{H}$ \\
\hline \multirow{3}{*}{ } & Thiol & $\begin{array}{c}+1.397 \\
(+1.117)\end{array}$ & $\begin{array}{l}-1.239 \\
(-1.198)\end{array}$ & $\begin{array}{c}-0.100 \\
(-0.081)\end{array}$ & $\begin{array}{c}+0.178 \\
(+0.176)\end{array}$ \\
\hline & Thiolate & $\begin{array}{c}+1.274 \\
(+1.083)\end{array}$ & $\begin{array}{l}-1.226 \\
(-1.213)\end{array}$ & $\begin{array}{c}-0.617 \\
(-0.599)\end{array}$ & $\begin{array}{l}- \\
--\end{array}$ \\
\hline & Thiolate/H & $\begin{array}{c}+1.281 \\
(+1.268)\end{array}$ & $\begin{array}{c}-\mathbf{- 0 . 8 0 0} \\
(-0.792)\end{array}$ & $\begin{array}{c}-0.615 \\
(-0.613)\end{array}$ & $\begin{array}{c}+0.176 \\
(+0.177)\end{array}$ \\
\hline \multirow{3}{*}{ } & Thiol & $\begin{array}{c}+1.201 \\
(+1.131)\end{array}$ & $\begin{array}{l}-1.276 \\
(-1.247)\end{array}$ & $\begin{array}{c}-0.114 \\
(-0.103)\end{array}$ & $\begin{array}{c}+0.181 \\
(+0.176)\end{array}$ \\
\hline & Thiolate & $\begin{array}{c}+1.014 \\
(+1.052)\end{array}$ & $\begin{array}{c}-1.271 \\
(-1.208)\end{array}$ & $\begin{array}{c}-0.597 \\
(-0.600)\end{array}$ & $\begin{array}{l}-- \\
--\end{array}$ \\
\hline & Thiolate/H & $\begin{array}{c}+1.122 \\
(+1.203)\end{array}$ & $\begin{array}{c}-\mathbf{- 0 . 7 8 9} \\
(-\mathbf{0 . 7 8 9})\end{array}$ & $\begin{array}{c}-0.599 \\
(-0.610)\end{array}$ & $\begin{array}{c}+0.176 \\
(+0.180)\end{array}$ \\
\hline \multirow{3}{*}{ 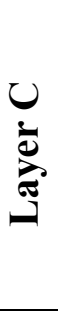 } & Thiol & $\begin{array}{c}+1.362 \\
(+1.303)\end{array}$ & $\begin{array}{c}-1.230 \\
\mathbf{( - 1 . 1 6 9 )}\end{array}$ & $\begin{array}{c}-0.096 \\
(-0.138)\end{array}$ & $\begin{array}{c}+0.172 \\
(+0.181)\end{array}$ \\
\hline & Thiolate & $\begin{array}{c}+1.263 \\
(+1.253)\end{array}$ & $\begin{array}{l}-1.244 \\
(-1.214)\end{array}$ & $\begin{array}{c}-0.613 \\
(-0.611) \\
\end{array}$ & $\begin{array}{l}-- \\
--\end{array}$ \\
\hline & Thiolate/H & $\begin{array}{c}+1.338 \\
(+1.236)\end{array}$ & $\begin{array}{c}-\mathbf{0 . 7 8 0} \\
(-\mathbf{- 0 . 8 2 0})\end{array}$ & $\begin{array}{c}-0.615 \\
(-0.569)\end{array}$ & $\begin{array}{c}+0.189 \\
(+0.183)\end{array}$ \\
\hline \multirow{3}{*}{ 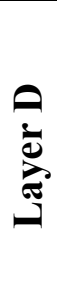 } & Thiol & $\begin{array}{c}+1.105 \\
(+1.120)\end{array}$ & $\begin{array}{l}-1.234 \\
(-1.215)\end{array}$ & $\begin{array}{c}-0.115 \\
(-0.093)\end{array}$ & $\begin{array}{c}+0.180 \\
(+0.176)\end{array}$ \\
\hline & Thiolate & $\begin{array}{c}+0.995 \\
(+1.026)\end{array}$ & $\begin{array}{c}-1.233 \\
(-1.209)\end{array}$ & $\begin{array}{c}-0.613 \\
(-0.602)\end{array}$ & $\begin{array}{l}-- \\
--\end{array}$ \\
\hline & Thiolate/H & $\begin{array}{c}+1.081 \\
(+1.079)\end{array}$ & $\begin{array}{c}-0.798 \\
(-0.783)\end{array}$ & $\begin{array}{c}-0.615 \\
(-0.595) \\
\end{array}$ & $\begin{array}{c}+0.169 \\
(+0.171)\end{array}$ \\
\hline
\end{tabular}




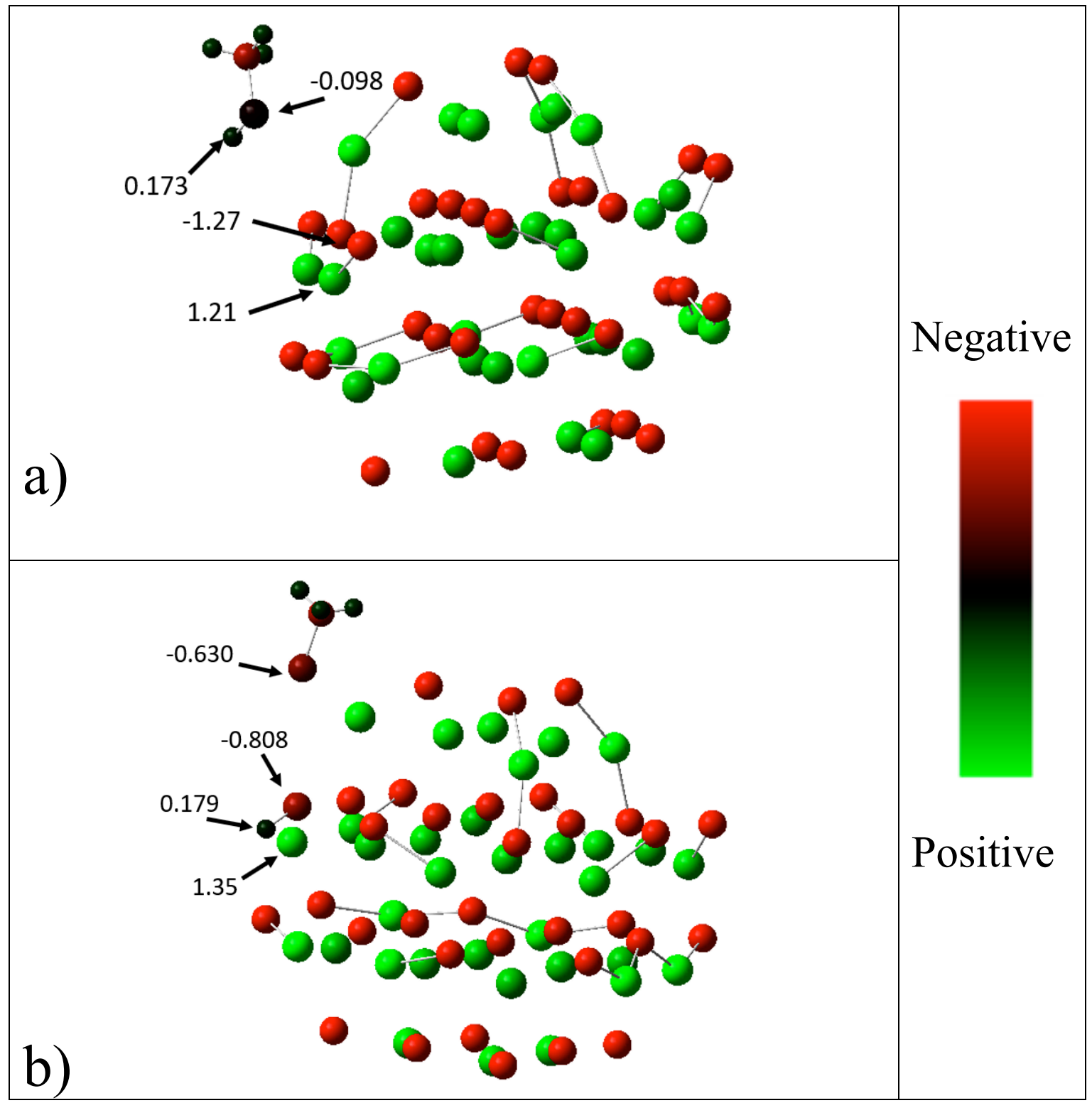

Figure S1: Natural bond orbital (NBO) charge distribution over atoms of the $(\mathrm{CdS})_{33} \mathrm{QD}$ passivated with one ligand of thiol (a), and thiolate/H (b) calculated in the acetonitrile solvent. In both cases, the ligand is attached to the layer A. The positive (green color) and negative (red color) charge is qualitatively shone at the scale bar. 


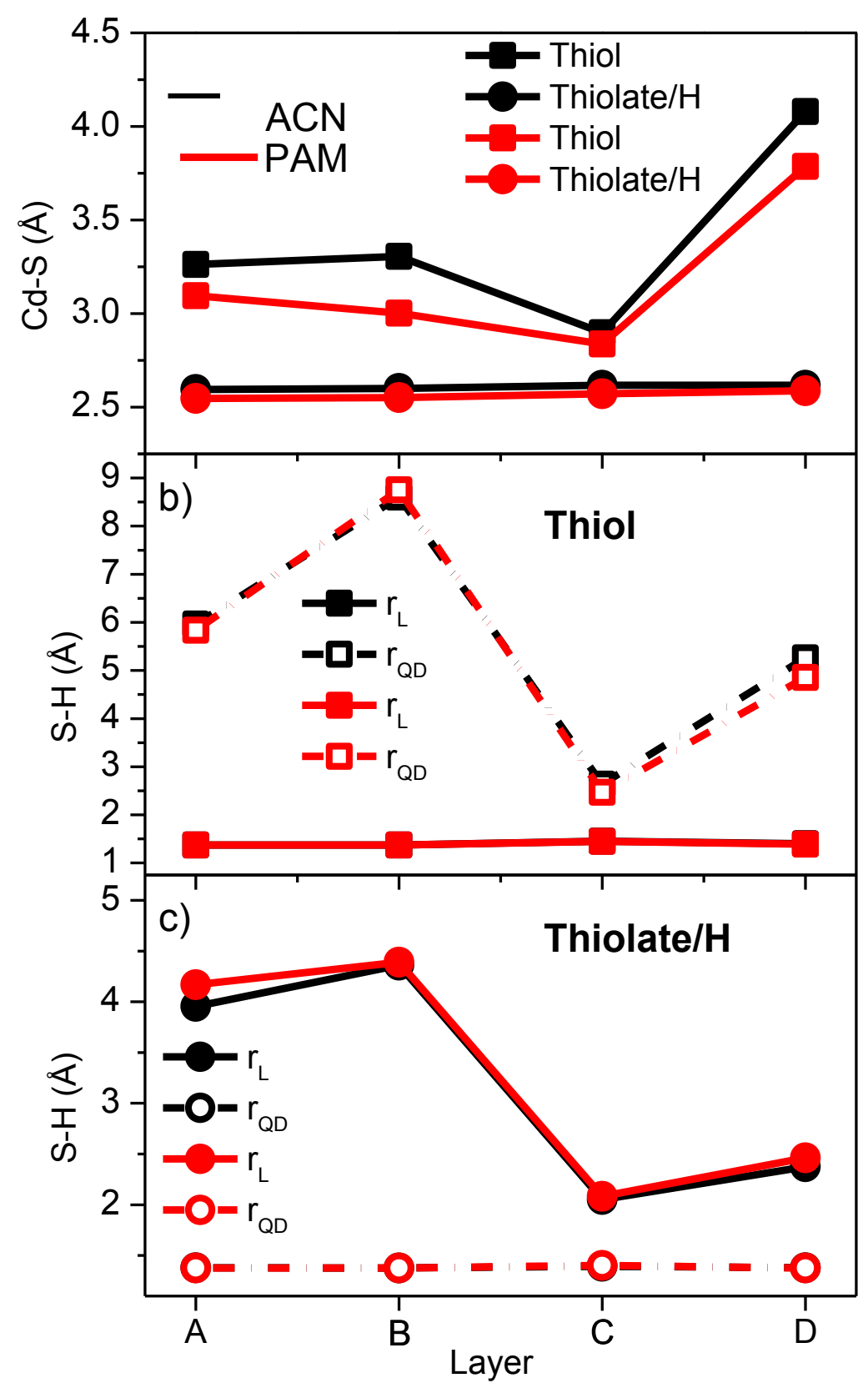

Figure S2: The Cd-S and S-H bond lengths of $(\mathrm{CdS})_{33}$ QDs with only one thiol or thiolate/H (bare) as a function of their position at the surface layers A-D in propylamine (red lines) and acetonitrile (black lines) solvents. (a) The Cd-S bond length between the surface $\mathrm{Cd}$ and $\mathrm{S}$ of the thiol (circles) or thiolate (squares). (b) The distance between $\mathrm{H}$ and $\mathrm{S}$ in the thiol (solid line, $\mathrm{r}_{\mathrm{L}}$ ) and $\mathrm{S}$ in the QD surface (dashed line, $\mathrm{r}_{\mathrm{QD}}$ ) of the Thiol structure. (c) The distance between $\mathrm{H}$ and $\mathrm{S}$ in the thiolate (solid line, $\mathrm{r}_{\mathrm{L}}$ ) and $\mathrm{S}$ in the $\mathrm{QD}$ surface (dashed line, $\mathrm{r}_{\mathrm{QD}}$ ) of the Thiolate/H structure. A noticeable reduction in $\mathrm{r}_{\mathrm{QD}}$ for the Thiol structure and $\mathrm{r}_{\mathrm{L}}$ for Thiolate/H structure at the $\mathrm{C}$-attachment points to the network formation when the proton is interacting with both sulfurs from the ligand and the QD. 

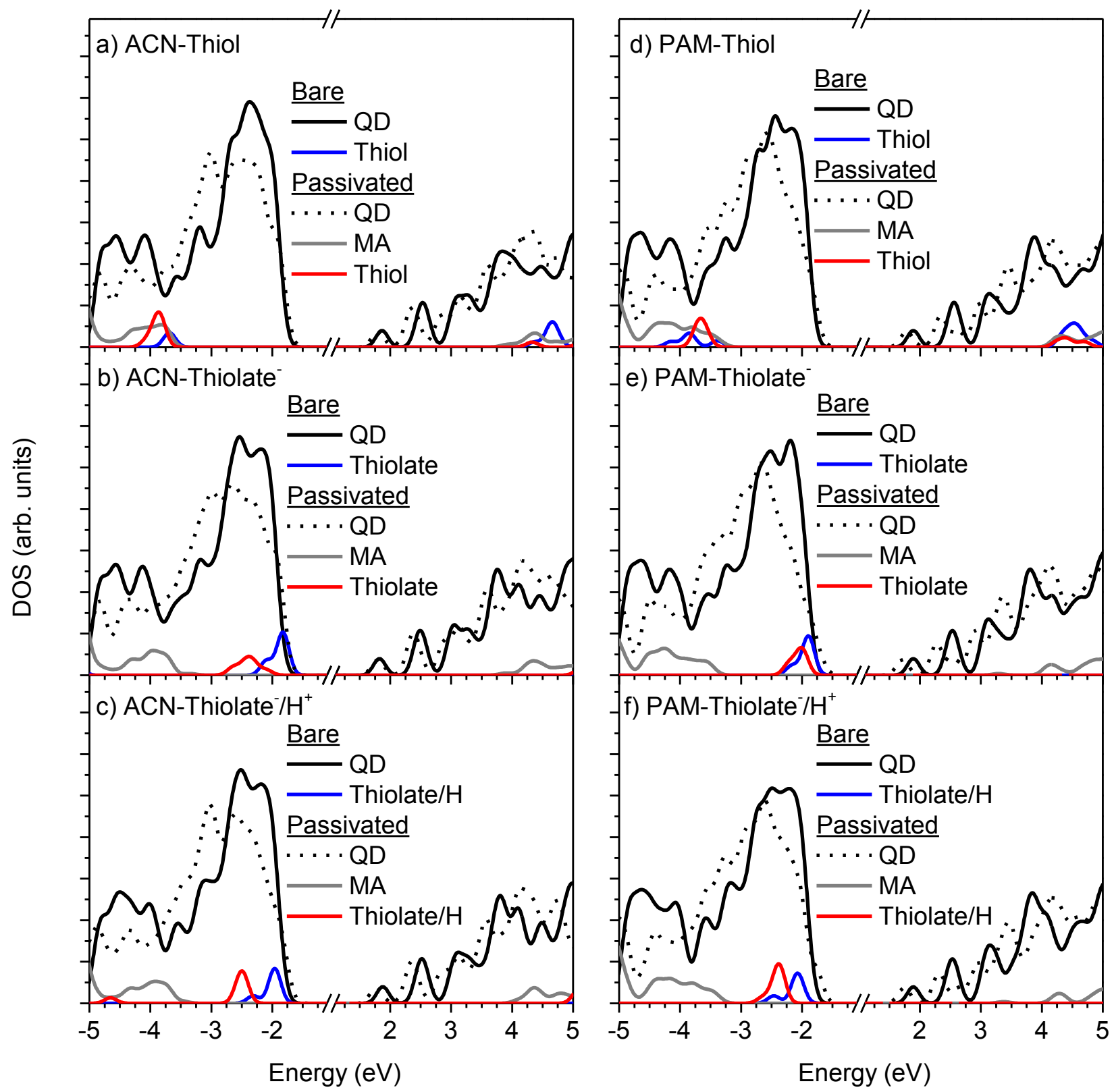

Figure S3: The density of states (DOS) projected to the orbitals originated from the QD, thiol, thiolate, thiolate $/ \mathrm{H}$, and methylamines (MA) in the bare QD with only one thiol-based ligand and fully passivated QD by 20 methylamines and one thiol-based ligand attached at the layer B. The panels (a-c) represent DOS in acetonitrile (ACN) and (d-f) in propylamine (PAM) solvents. The DOS contribution of the thiol, thiolate, and thiolate $/ \mathrm{H}$ is multiplied by 3 for better visualization. (a) and (d) Thiol structures, (b) and (e) Thiolate structures, and (c) and (f) Thiolate/H structures. 

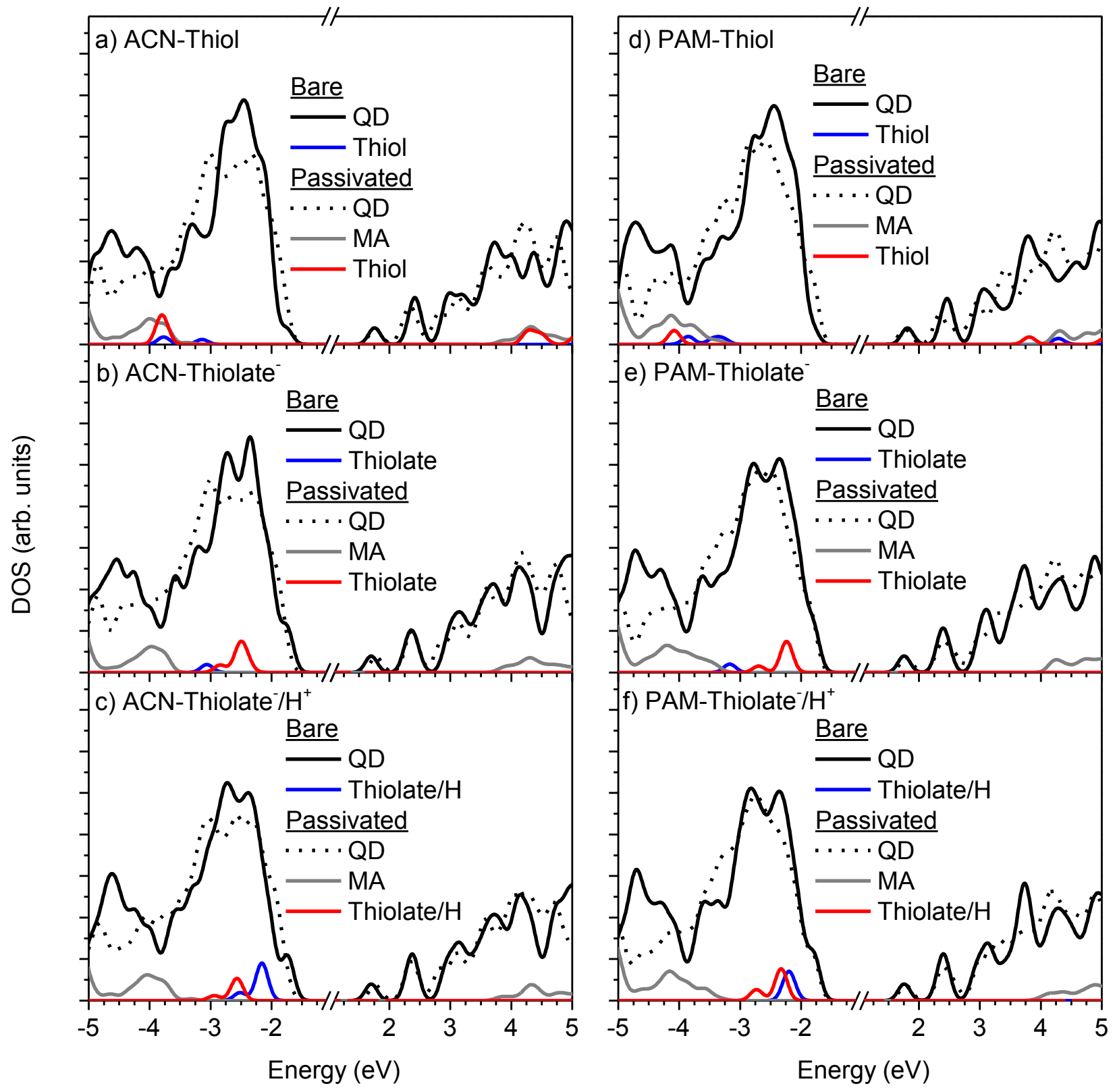

Figure S4: The density of states (DOS) projected to the orbitals originated from the QD, thiol, thiolate, thiolate/H, and methylamines (MA) in the bare QD with only one thiol-based ligand and fully passivated QD by 20 methylamines and one thiol-based ligand attached at the layer $\mathbf{C}$. The panels (a-c) represent DOS in acetonitrile (ACN) and (d-f) in propylamine (PAM) solvents. The DOS contribution of the thiol, thiolate, and thiolate $/ \mathrm{H}$ is multiplied by 3 for better visualization. (a) and (d) Thiol structures, (b) and (e) Thiolate structures, and (c) and (f) Thiolate/H structures. 

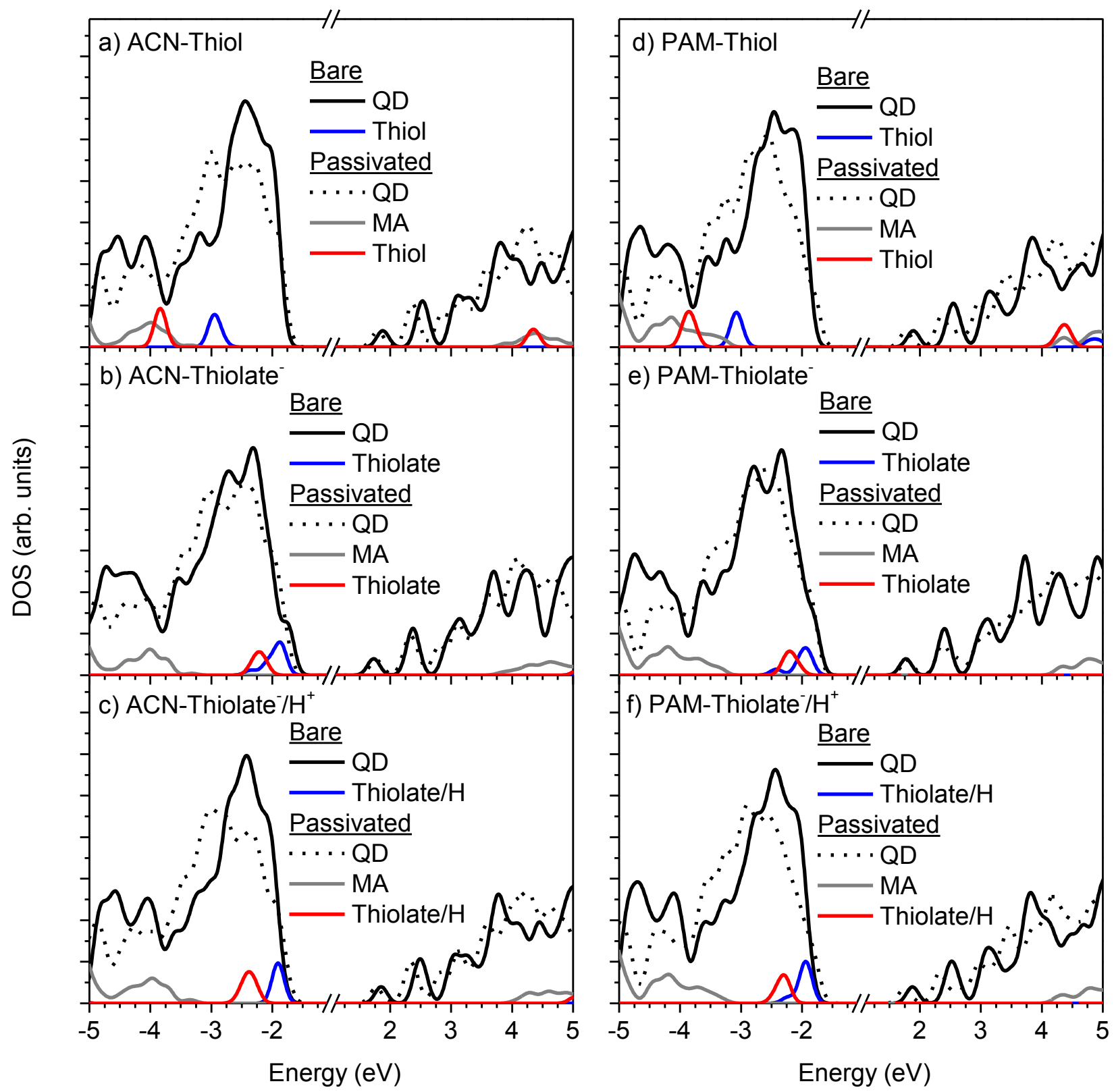

Figure S5: The density of states (DOS) projected to the orbitals originated from the QD, thiol, thiolate, thiolate/H, and methylamines (MA) in the bare QD with only one thiol-based ligand and fully passivated QD by 20 methylamines and one thiol-based ligand attached at the layer $\mathbf{D}$. The panels (a-c) represent DOS in acetonitrile (ACN) and (d-f) in propylamine (PAM) solvents. The DOS contribution of the thiol, thiolate, and thiolate/H is multiplied by 3 for better visualization. (a) and (d) Thiol structures, (b) and (e) Thiolate structures, and (c) and (f) Thiolate/H structures. 


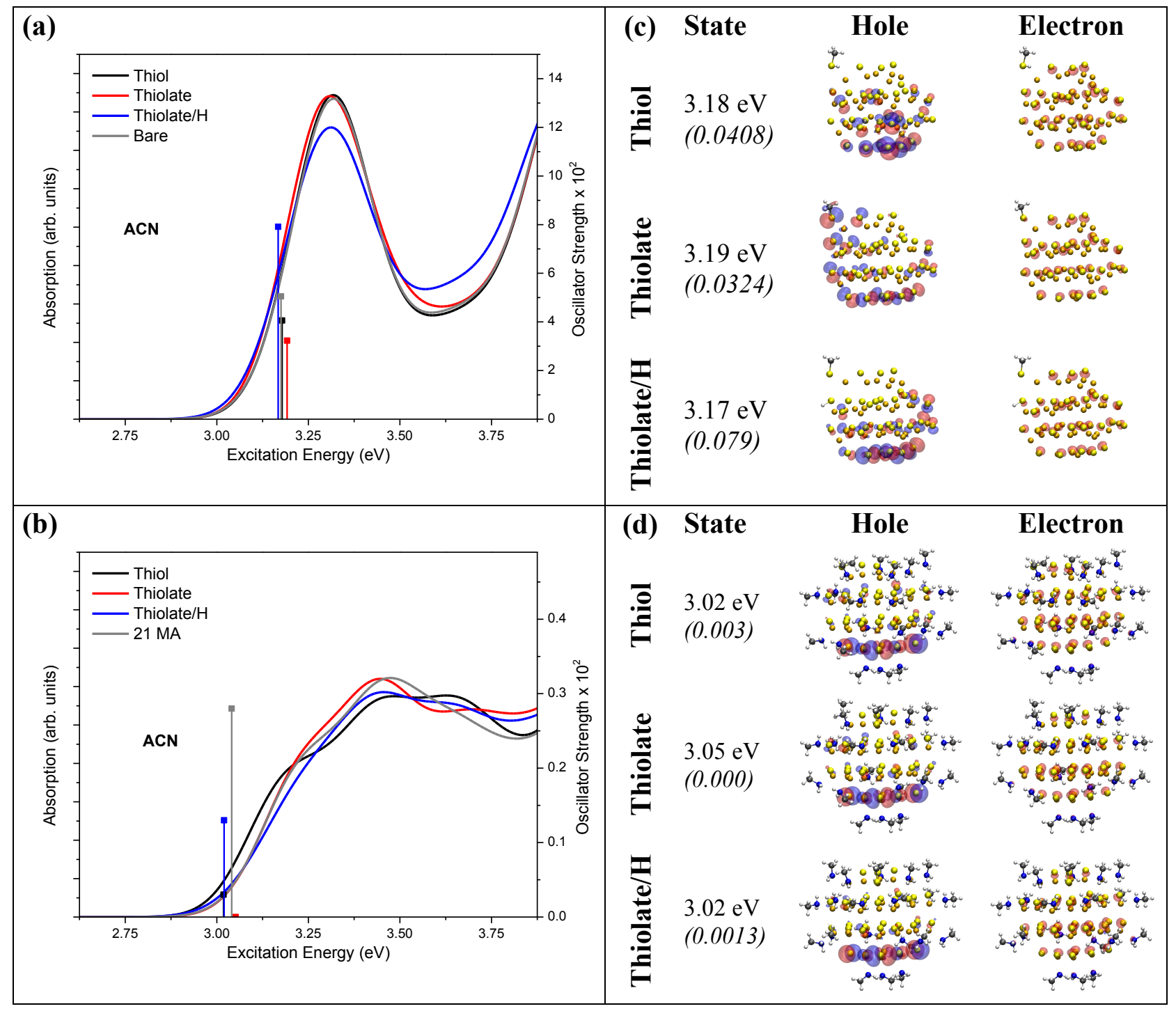

Figure S6: The Absorption spectra and natural transition orbitals (NTOs) presenting the electron-hole pair contributing to the lowest optical transition of the bare QD with only one thiolbased ligand (a) and (c) and fully passivated QD by 20 methylamines and one thiol-based ligand (b) and (d) attached at the layer $\mathrm{A}$ and calculated in acetonitrile (ACN). As a reference, the spectra of the bare QD without any ligands (a) and fully passivated by 21 amines (b) are shown by grey lines. The vertical lines introduce the lowest energy transition for each structure, with its oscillator strength represented at the right $\mathrm{Y}$-axis. The oscillator strengths of the lowest transition are represented by values in pretenses in (c) and (d). 


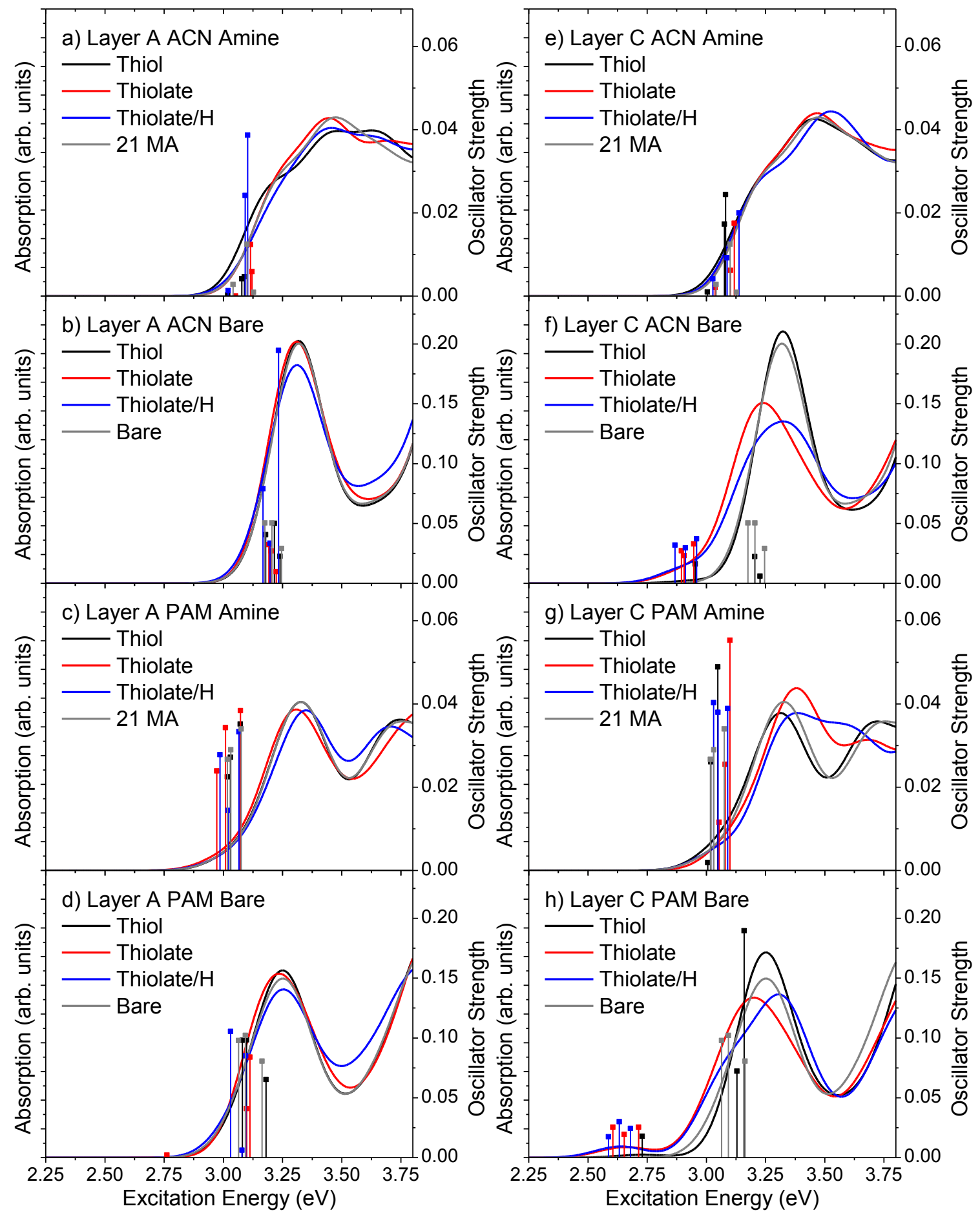

Figure S7: The Absorption spectra of the bare QD with only one thiol-based ligand and fully passivated QD by 20 methylamines and one thiol-based ligand attached at the layer A (a)-(d) or the layer $\mathrm{C}(\mathbf{e})-(\mathbf{h})$ calculated in acetonitrile $(\mathrm{ACN})$ and propylamine (PAM) solvents. As a reference, the spectra of the bare QD without any ligands (Bare) and fully passivated by 21 amines (Amine) are shown by grey lines. The vertical lines introduce three lowest energy transitions for each structure, with its oscillator strength represented at the right Y-axis. 


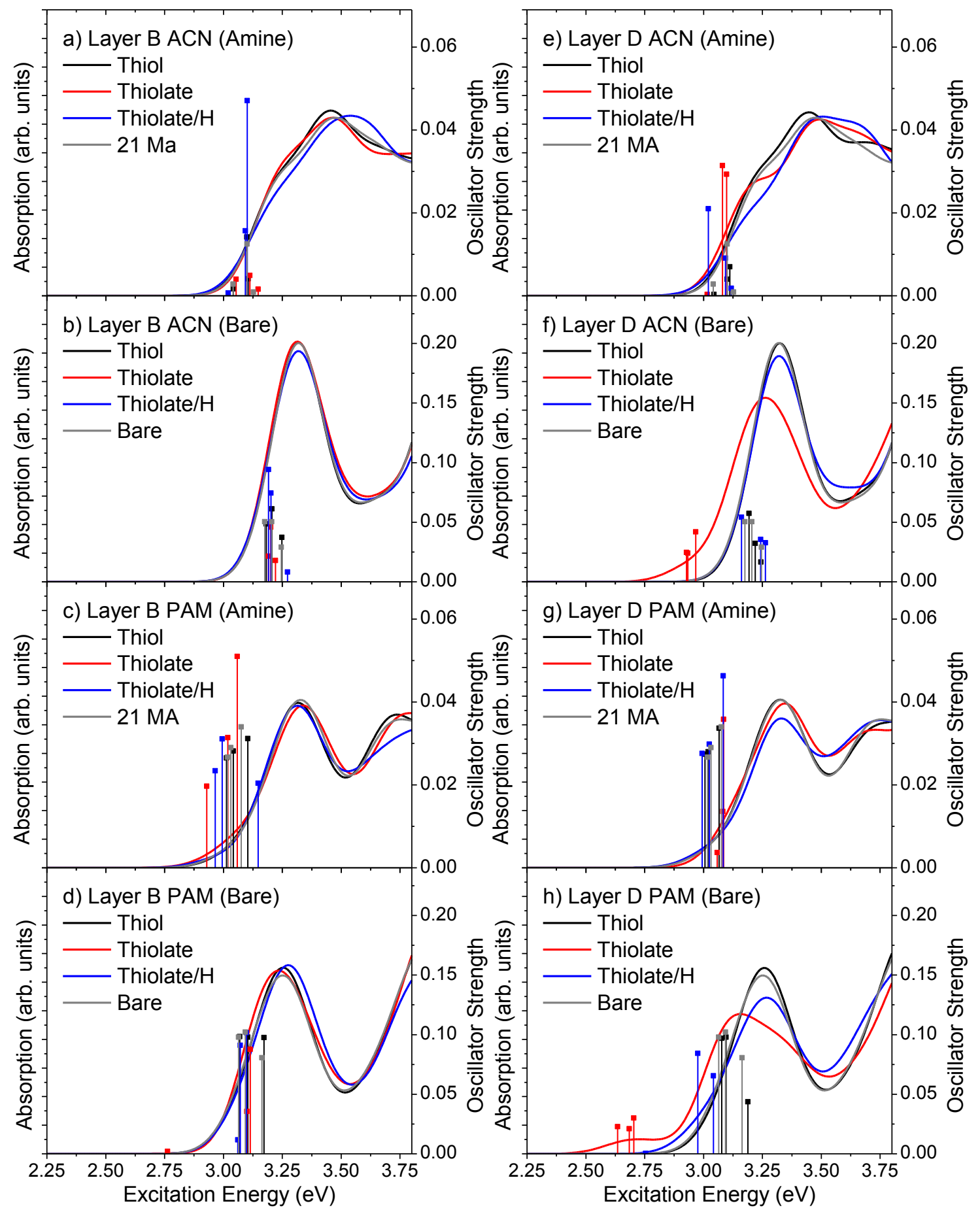

Figure S8: The Absorption spectra of the bare QD with only one thiol-based ligand and fully passivated QD by 20 methylamines and one thiol-based ligand attached at the layer B (a)-(d) or the layer D (e)-(h) calculated in acetonitrile $(\mathrm{ACN})$ and propylamine (PAM) solvents. As a reference, the spectra of the bare QD without any ligands (Bare) and fully passivated by 21 amines (Amine) are shown by grey lines. The vertical lines introduce three lowest energy transitions for each structure, with its oscillator strength represented at the right $\mathrm{Y}$-axis. 
Table S2: Natural Transition Orbitals (NTOs) representing the electron-hole pair contributing to the lowest optical transition $\left(\mathrm{S}_{1}\right)$ of the bare $(\mathrm{CdS})_{33}$ QD with only one thiol-based ligand and the $(\mathrm{CdS})_{33}$ QD fully passivated by 20 methylamines and one thiol-based ligand attached at the layer $\mathrm{A}$ or $\mathrm{C}$ and calculated in acetonitrile $(\mathrm{ACN})$ and propylamine (PAM) solvents. The oscillator strength of the transition is indicated in prentices.

\begin{tabular}{|c|c|c|c|c|c|c|c|}
\hline & \multirow{2}{*}{ State } & \multicolumn{2}{|c|}{20 Amine } & \multirow{2}{*}{ State } & \multicolumn{2}{|c|}{ Bare } \\
\hline & & & hole & electron & & hole & electron \\
\hline \multirow{4}{*}{$\frac{\bar{o}}{\frac{0}{f}}$} & \multirow{2}{*}{ Ż } & $\begin{array}{l}\text { Layer A } \\
3.02 \mathrm{eV} \\
(0.000)\end{array}$ & 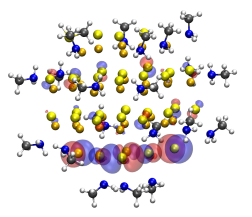 & 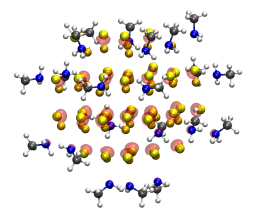 & $\begin{array}{l}\text { Layer A } \\
3.18 \mathrm{eV} \\
(0.041)\end{array}$ & 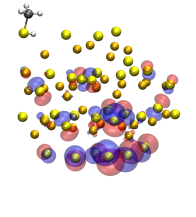 & 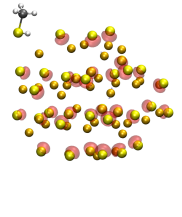 \\
\hline & & $\begin{array}{l}\text { Layer C } \\
3.00 \mathrm{eV} \\
(0.001)\end{array}$ & 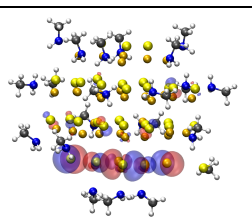 & 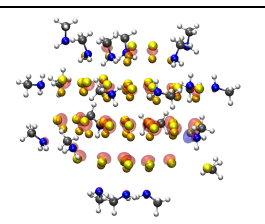 & $\begin{array}{l}\text { Layer C } \\
2.95 \mathrm{eV} \\
(0.016)\end{array}$ & 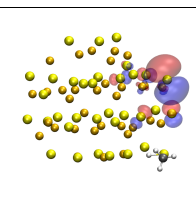 & 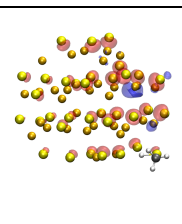 \\
\hline & \multirow{2}{*}{$\sum_{\Omega}$} & $\begin{array}{l}\text { Layer A } \\
3.02 \mathrm{eV} \\
(0.023)\end{array}$ & 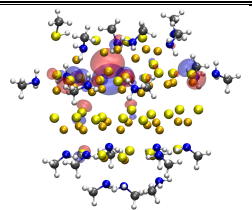 & 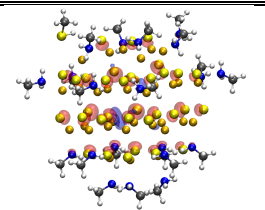 & $\begin{array}{l}\text { Layer A } \\
3.08 \mathrm{eV} \\
(0.099)\end{array}$ & 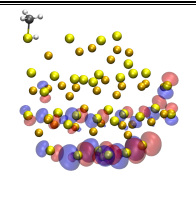 & 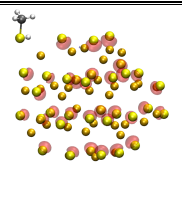 \\
\hline & & $\begin{array}{l}\text { Layer C } \\
\begin{array}{l}3.01 \mathrm{eV} \\
(0.002)\end{array}\end{array}$ & 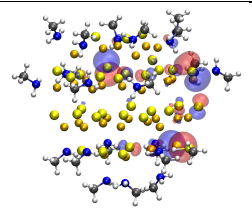 & 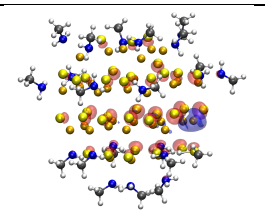 & $\begin{array}{l}\text { Layer C } \\
2.73 \mathrm{eV} \\
(0.018)\end{array}$ & 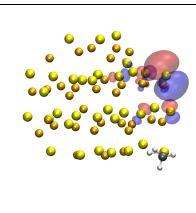 & 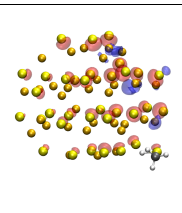 \\
\hline \multirow{4}{*}{$\begin{array}{l}\frac{0}{\pi} \\
\frac{\pi}{0} \\
\frac{0}{E} \\
F\end{array}$} & \multirow{2}{*}{ Z } & $\begin{array}{l}\text { Layer A } \\
3.05 \mathrm{eV} \\
(0.000)\end{array}$ & 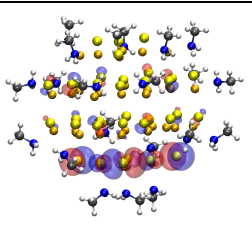 & 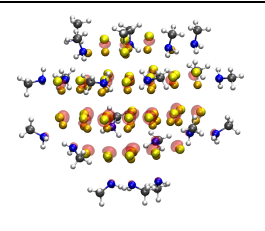 & $\begin{array}{l}\text { Layer A } \\
3.19 \mathrm{eV} \\
(0.032)\end{array}$ & 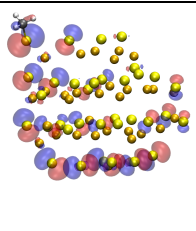 & 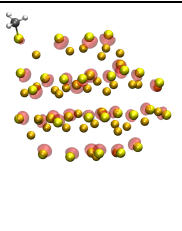 \\
\hline & & $\begin{array}{l}\text { Layer C } \\
\\
3.04 \mathrm{eV} \\
(0.002)\end{array}$ & 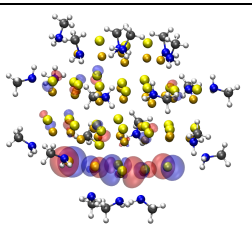 & 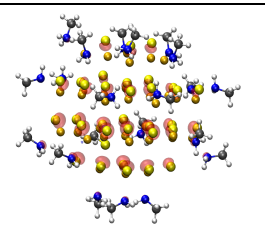 & $\begin{array}{l}\text { Layer C } \\
2.89 \mathrm{eV} \\
(0.027)\end{array}$ & 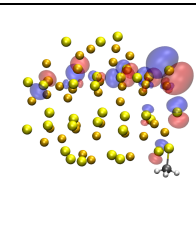 & 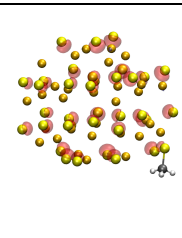 \\
\hline & \multirow{2}{*}{$\sum_{\Sigma}$} & $\begin{array}{l}\text { Layer A } \\
\\
2.97 \mathrm{eV} \\
(0.024)\end{array}$ & 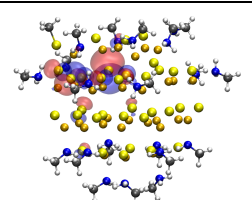 & 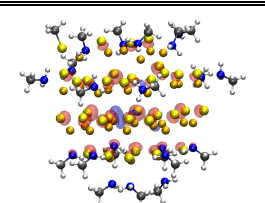 & $\begin{array}{l}\text { Layer A } \\
2.76 \mathrm{eV} \\
(0.002)\end{array}$ & 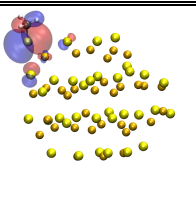 & 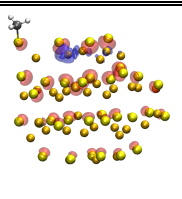 \\
\hline & & $\begin{array}{l}\text { Layer C } \\
\begin{array}{l}3.05 \mathrm{eV} \\
(0.012)\end{array}\end{array}$ & 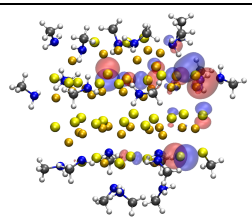 & 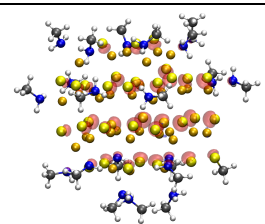 & $\begin{array}{l}\text { Layer C } \\
2.61 \mathrm{eV} \\
(0.026)\end{array}$ & 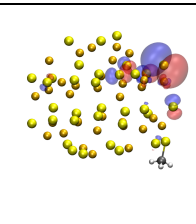 & 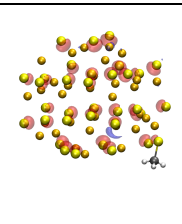 \\
\hline
\end{tabular}




\begin{tabular}{|c|c|c|c|c|c|c|c|}
\hline & \multirow{2}{*}{ State } & \multicolumn{2}{|c|}{20 Amine } & \multirow{2}{*}{ State } & \multicolumn{2}{|c|}{ Bare } \\
\hline & & & hole & electron & & hole & electron \\
\hline \multirow{4}{*}{ 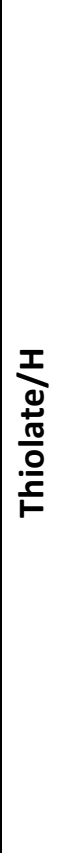 } & \multirow{2}{*}{ Z } & $\begin{array}{l}\text { Layer A } \\
3.02 \mathrm{eV} \\
(0.001)\end{array}$ & 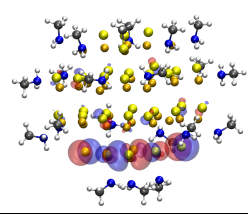 & 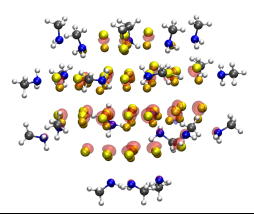 & $\begin{array}{l}\text { Layer A } \\
3.17 \mathrm{eV} \\
(0.079)\end{array}$ & 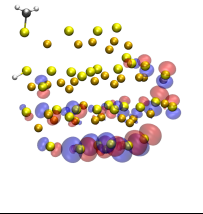 & 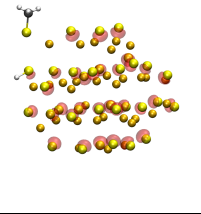 \\
\hline & & $\begin{array}{l}\text { Layer C } \\
3.03 \mathrm{eV} \\
(0.004)\end{array}$ & 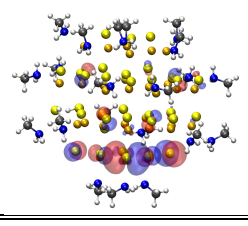 & 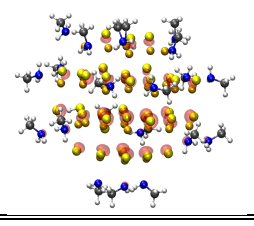 & $\begin{array}{l}\text { Layer C } \\
2.87 \mathrm{eV} \\
(0.032)\end{array}$ & 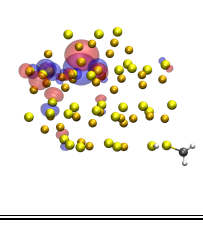 & 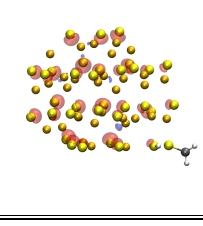 \\
\hline & \multirow{2}{*}{$\sum_{a}$} & $\begin{array}{l}\text { Layer A } \\
2.99 \mathrm{eV} \\
(0.028)\end{array}$ & 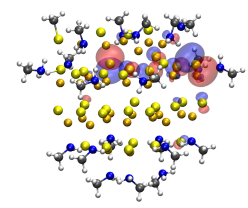 & 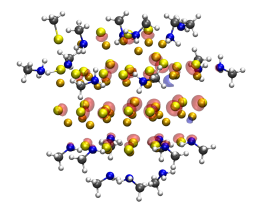 & $\begin{array}{l}\text { Layer A } \\
3.03 \mathrm{eV} \\
(0.106)\end{array}$ & 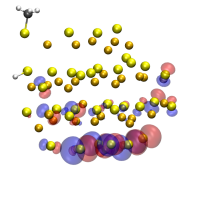 & 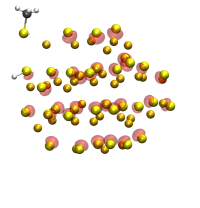 \\
\hline & & $\begin{array}{l}\text { Layer C } \\
3.03 \mathrm{eV} \\
(0.040)\end{array}$ & 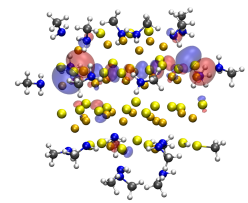 & 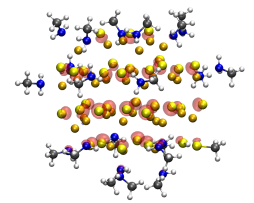 & $\begin{array}{l}\text { Layer C } \\
2.59 \mathrm{eV} \\
(0.017)\end{array}$ & 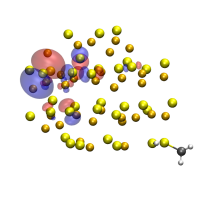 & 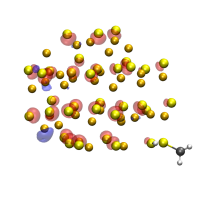 \\
\hline
\end{tabular}

Table S3: Natural Transition Orbitals (NTOs) representing the electron-hole pair contributing to two lowest optical transition $\left(\mathrm{S}_{1}\right.$ and $\left.\mathrm{S}_{2}\right)$ of the bare $(\mathrm{CdS})_{33} \mathrm{QD}$ without any passivating ligands and fully passivated by 21 methylamines calculated in acetonitrile (ACN) and propylamine (PAM) solvents. The oscillator strength of the transition is indicated in prentices.

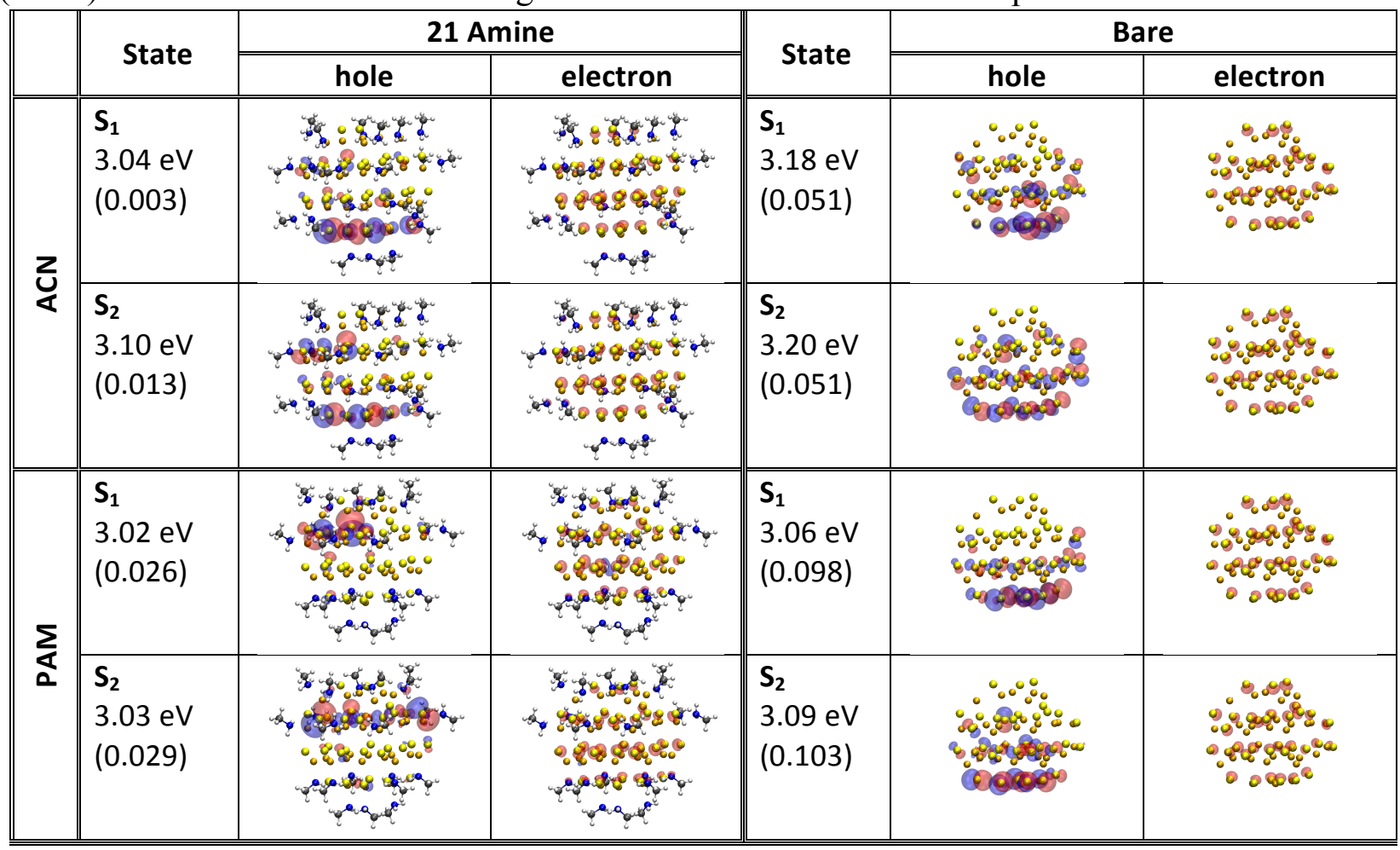




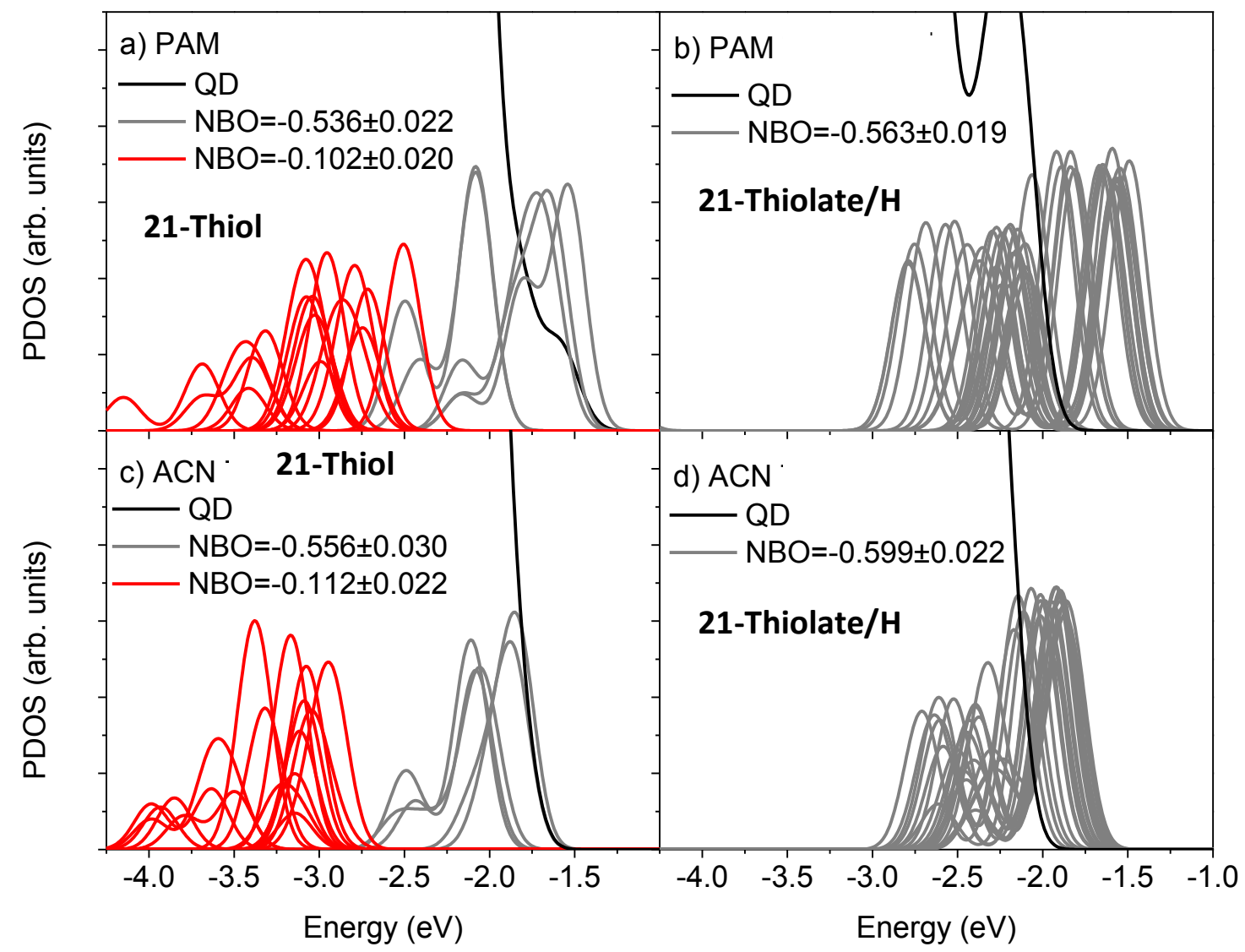

Figure S9: Projected Density of States (PDOS) of the (CdS $)_{33}$ QD passivated by 21 thiol-based ligands initially set up as 21-Thiol (a and c) or 21-Thiolate/H (b and d) structures. The black line represents the QD-originated states. The ligand states are fragmented based on the value of the NBO charge of their sulfur, with the red lines indicating the charge ranging from -0.07 to $-0.16 \mathrm{e}$ and the grey lines showing the charge ranging from -0.50 to -0.63 . 


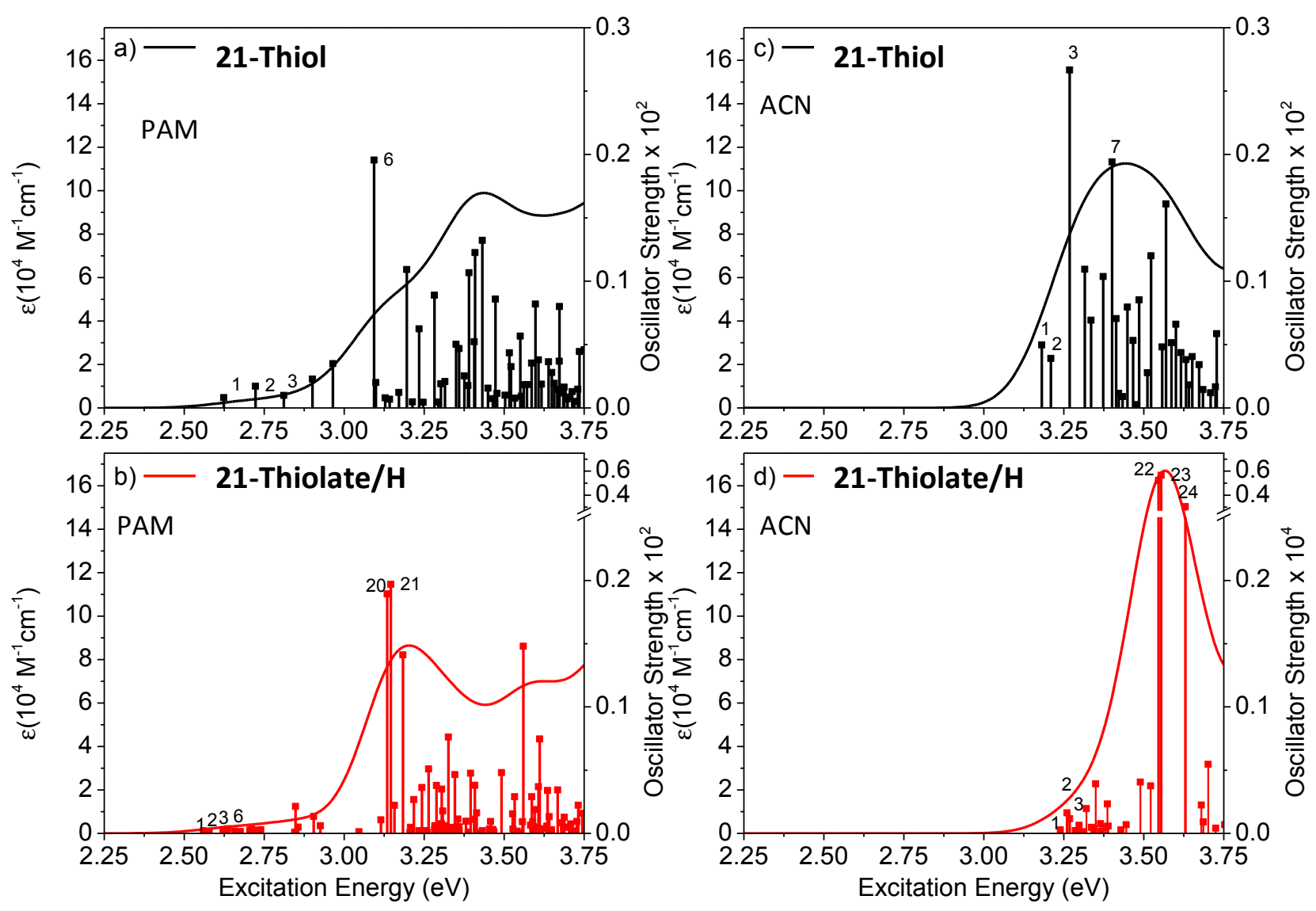

Figure S10: Absorption spectrum for fully passivated $(\mathrm{CdS})_{33}$ QDs with 21 thiols (a and c) or thiolate/H (b and d) calculated in acetonitrile (ACN) and propylamine (PAM) solvents. The vertical lines introduce optical transitions for each structure, with its oscillator strength represented at the right Y-axis. 

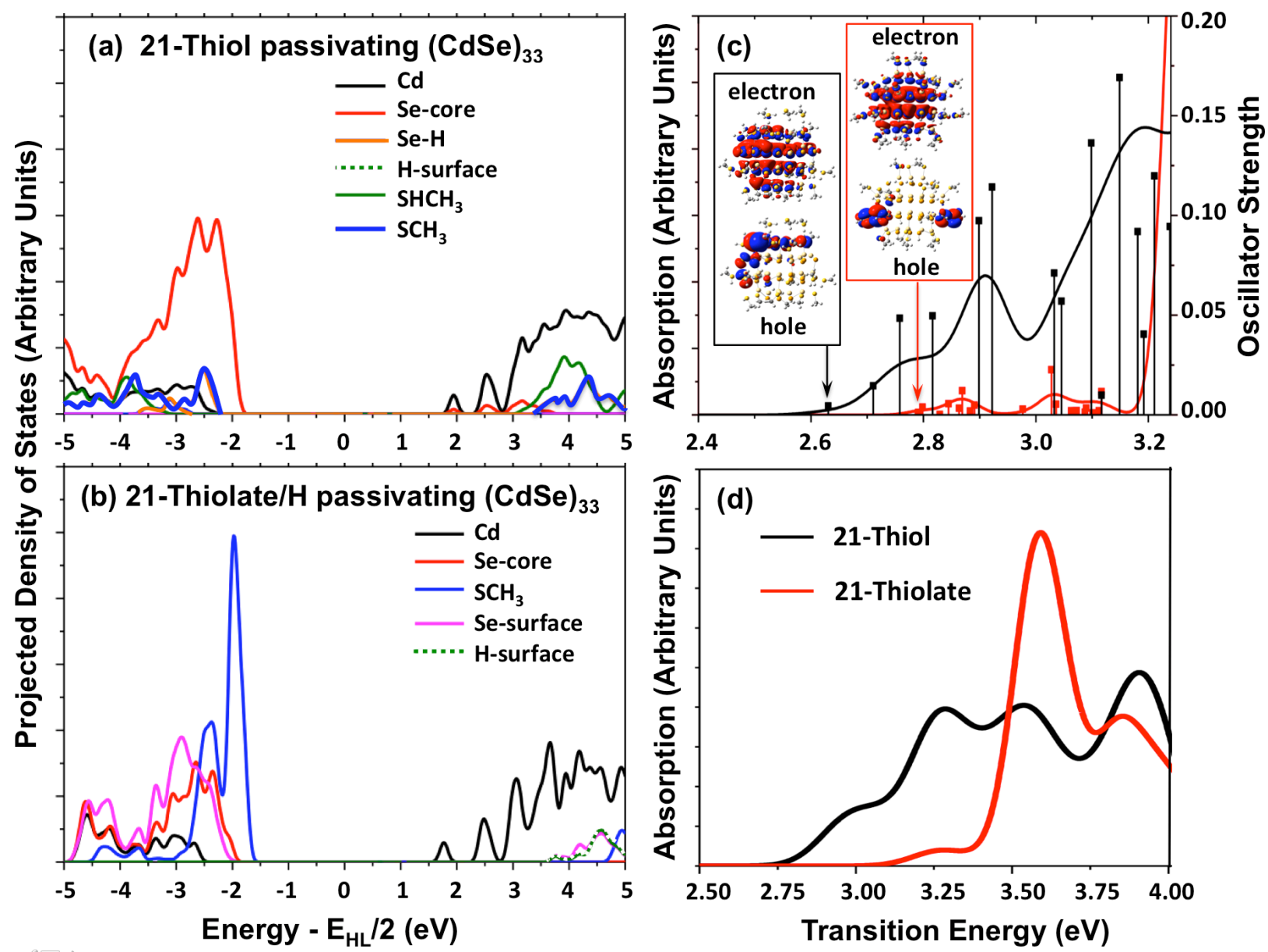

Figure S11: The ground state and excited state electronic spectra of $(\mathrm{CdSe})_{33}$ QD passivated by 21 thiols and 21 thiolate/ $\mathrm{H}$ in acetonitrile solvent. (a) and (b) The density of states projected to different parts of the system: the $\mathrm{Cd}$ and $\mathrm{Se}$ atoms of the QD, thiols, thiolates, and the proton interacting with the QD surface. (c) and (d) Absorption spectra of 21-Thiol (black line) and 21Thiolate/H (red line) systems. The vertical lines in (c) introduce optical transitions for each structure, with its oscillator strength represented at the right Y-axis. Inserts show the NTOS depicting the electron-hole pair contributing to the lowest optical transition. Localization of the hole on thiolate ligands, while the electron is delocalized over the QD, results in optically inactive lowest transitions in 21-Thiolate/H system. In contrast, more delocalized character of the hole in 21-Thiol structure due to contributions of the thiol-H-QD network, leads to optically active transition, followed by a bunch of highly intensive transitions, which favors the emission. 


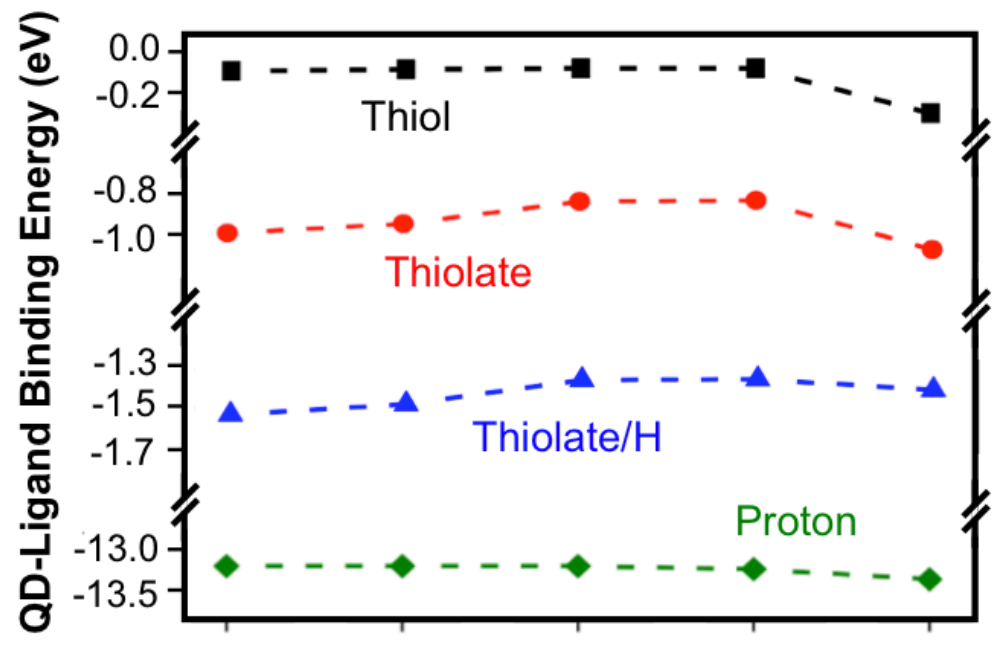

\section{$\mathrm{L}(\mathrm{Cd}, \mathrm{S}) / 6-31 \mathrm{~g}^{*} \mathrm{~L} / 6-31 \mathrm{~g}^{*} \mathrm{~L} / 6-31^{+} \mathrm{g}^{*} \mathrm{~L} / 6-311^{+} \mathrm{g}^{*}$ Def/6-311 ${ }^{*} \mathrm{~g}^{*}$}

Figure S12: The binding energies of the thiol, thiolate, and proton to the $(\mathrm{CdS})_{33} \mathrm{QD}$ when they placed at the layer $\mathrm{C}$ and optimized using different basis sets in propylamine solvent. All structures are calculated without methylamines ligands present at the QD surface using PBE0 functional. For all cases, L stands for LANL2DZ basis set which is used for atoms of the QD (Cd and $\mathrm{S})$. The notation $\mathrm{L}(\mathrm{Cd}, \mathrm{S}) / 6-31 \mathrm{~g} *$ corresponds to the basis set when all $\mathrm{Cd}$ and $\mathrm{S}$ atoms, including the $\mathrm{S}$ in the thiol/thiolate ligand, are treated using LANL2DZ, and 6-31g* represents the basis set used for all atoms of the ligand. For the remaining basis set combinations, the notations after the backslash correspond to the related basis set used for ligand atoms. The notation Def represents the Def2TZVP basis set that is used for the QD atoms

It is known that the binding energy can be strongly affected by the basis set superposition error (BSSE). In our previous work ${ }^{1}$, we have studied the effect of BSSE using the counterpoise method $(\mathrm{CP})$ applied to calculations of the ligand- QD binding energy for the $(\mathrm{CdSe})_{33}$ QD and the trimethyl-phosphine oxide (OPMe3) ligand. It was shown that inclusion of $\mathrm{CP}$ correction to the LANL2DZ/6-31G* basis set reduces the ligand binding energy by $\sim 0.2 \mathrm{eV}$, but has a little effect $(\sim 0.06 \mathrm{eV})$ for larger basis sets, starting with LANL2DZ/6-31 $1^{+} \mathrm{G}^{*}$, if calculations are done in vacuum. While the $\mathrm{CP}$ correction allows one to obtain fairly accurate binding energies with relatively small basis sets such as LANL2DZ/6-31G*, its evaluation is as expensive computationally as the use of a more extended basis set such as LANL2DZ $/ 6-31^{+} \mathrm{G}^{*}$. Inclusion of a polar solvent significantly screens the binding energy, while does not change the relative difference between results obtained with LANL2DZ/6-31G* and larger basis sets.

To verify that these conclusions from Ref. 1 are applicable to our systems, we calculated the QDligand binding energies using several larger size basis sets, as shown in Fig. S12. These calculations confirm the same trend in the basis size dependence of the binding energy of the thiol and thiolate ligands to the $(\mathrm{CdSe})_{33}$ QD as was observed in Ref. 1 for the binding energy 
between the $(\mathrm{CdSe})_{33} \mathrm{QD}$ and the $\mathrm{OPMe}_{3}$ ligand: Usage of larger size basis set for ligands, such as $6-31^{+} \mathrm{G}^{*}$ and $6-311^{+} \mathrm{G}^{*}$, destabilize the QD-ligand binding energy by about $0.2 \mathrm{eV}$, compared to those obtained by $6-31 \mathrm{G}^{*}$. However, this does not change the overall trends between thiol and thiolate ligands. Independent on the used basis set, thiolate binds to the QD significantly stronger than thiol, while the appearance of a proton on the adjacent surface sulfur provides additional stabilization of the QD-thiolate binding energy. As such, we can conclude that increasing the basis set do not change the obtained results with the LANL2DZ/6-31G* basis set, it does not affect the overall trends in the thiol and thiolate binding to the QD surface.
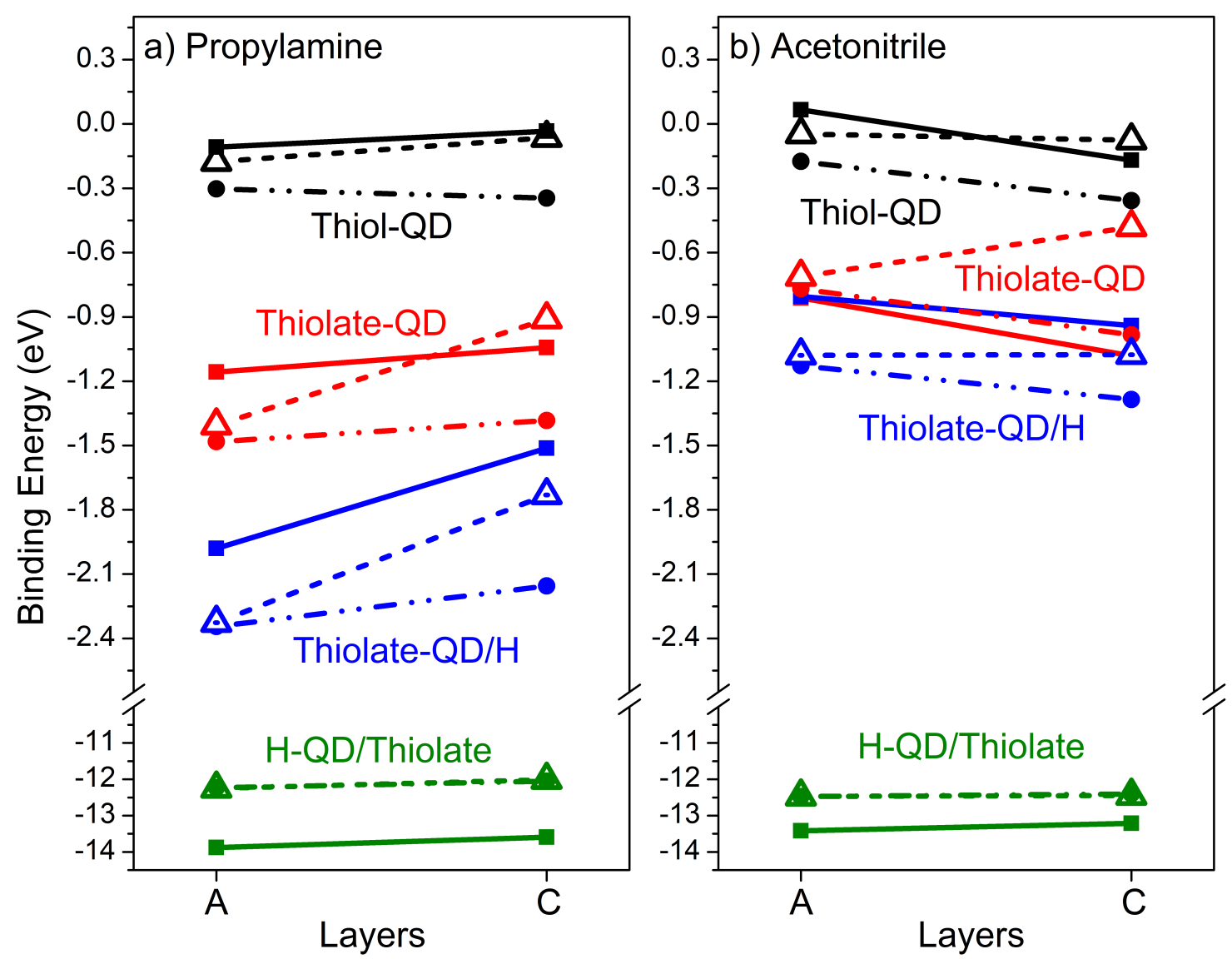

Figure S13: Comparing the binding energy on layers $\mathrm{A}$ and $\mathrm{C}$ of bare $(\mathrm{CdS})_{33}$ with a single ligand in propylamine (a) and acetonitrile (b) using PBE0 (solid lines with filled squares), $\omega$ B07XD (Dot-Dashed lines with filled circles) and CAM-B3LYP (Dash lines with empty triangles) functionals with mixed basis sets (LANL2DZ for Cd and S, 6-31g* $\mathrm{H}$ and C).

The effect of functionals on the QD-ligand binding energy was studied in Ref 1. It was showing that the long-range corrected functionals stabilize the ligand-QD binding energy by about 0.15 $\mathrm{eV}$, compared to the hybrid functionals such as PBE0 and B3LYP, both in vacuum and a polar solvent. To prove that this conclusion from Ref. 1 is applicable to our systems, we calculated the QD-ligand binding energies using $\omega$ B97XD and CAM-B3LYP and compared to PBE0 results, as shown in Fig. S13 in SI (new). For all structures, the geometries were optimized using these 
three functionals and LANL2DZ/6-31G* basis set in propylamine and acetonitrile solvents. For the A-layer attachment, both long-range corrected functionals stabilize the QD-ligand binding energy for both thiol and thiolate ligands by $0.15-0.35 \mathrm{eV}$, compared to those calculated by PBE0 functional. This trend is similar in propylamine and acetonitrile, except the thiolate-QD binding energy in acetonitrile that is nearly the same for all functionals. Interestingly, while the binding energy values differ by less than $0.15 \mathrm{eV}$ between CAM-B3LYP and $\omega \mathrm{B} 97 \mathrm{XD}$ for the A-layer attachment, CAM-B3LYP noticeably destabilizes the QD-ligand binding energy for both thiolate and thiols at the C-layer, compared to those calculated by $\omega \mathrm{B} 97 \mathrm{XD}$ (with the most pronounced trend for the Thiolate system). This change between functionals is associated with the difference in the optimized geometry obtained by CAM-B3LYP compared to the other functionals. Both PBE0 and $\omega \mathrm{B} 97 \mathrm{XD}$ result to the ligand binding at the edge between layers $\mathrm{C}$ and $\mathrm{D}$, thus increasing the QD-ligand interaction, while CAM-B3LYP does not provide the edge conformation, leaving the ligand at the C-layer position.

Thus, we can conclude that despite the difference in the values of the QD-ligand binding energy, a qualitative performance of the PBE0 functional is close to the $\omega \mathrm{B} 97 \mathrm{XD}$, which is expected to be more accurate than CAM-B3LYP due to inclusion of the dispersion corrections. ${ }^{2}$ In addition, the choice of the functional does not change the qualitative trends in the strength of the thiol and thiolate bindings: The deprotonation of the thiol results in a stronger thiolate-QD interaction than thiol-QD. This stability is further facilitated by the proton attachment to the nearest sulfur at the QD surface (Thiolate/H). These trends are more pronounced in less polar solvents, since a polar solvent screens the QD-ligand interactions.

We also investigated the effect of the functional on the electronic structure of studied systems, Fig. S14. As expected, both the states associated with the QD and the states of the thiol and thiolate ligands, as well as their relative alignment are insignificantly affected by the functionals, exhibiting identical trends. Independent on the QD surface, the electronic states originated from the thiol contribute only deep inside the valence band (VB), while the thiolate-associated states for the Thiolate and Thiolate/H structures appear much closer to the VB edge or at the VB edge, leading to the ligand-originated hole trap states. 

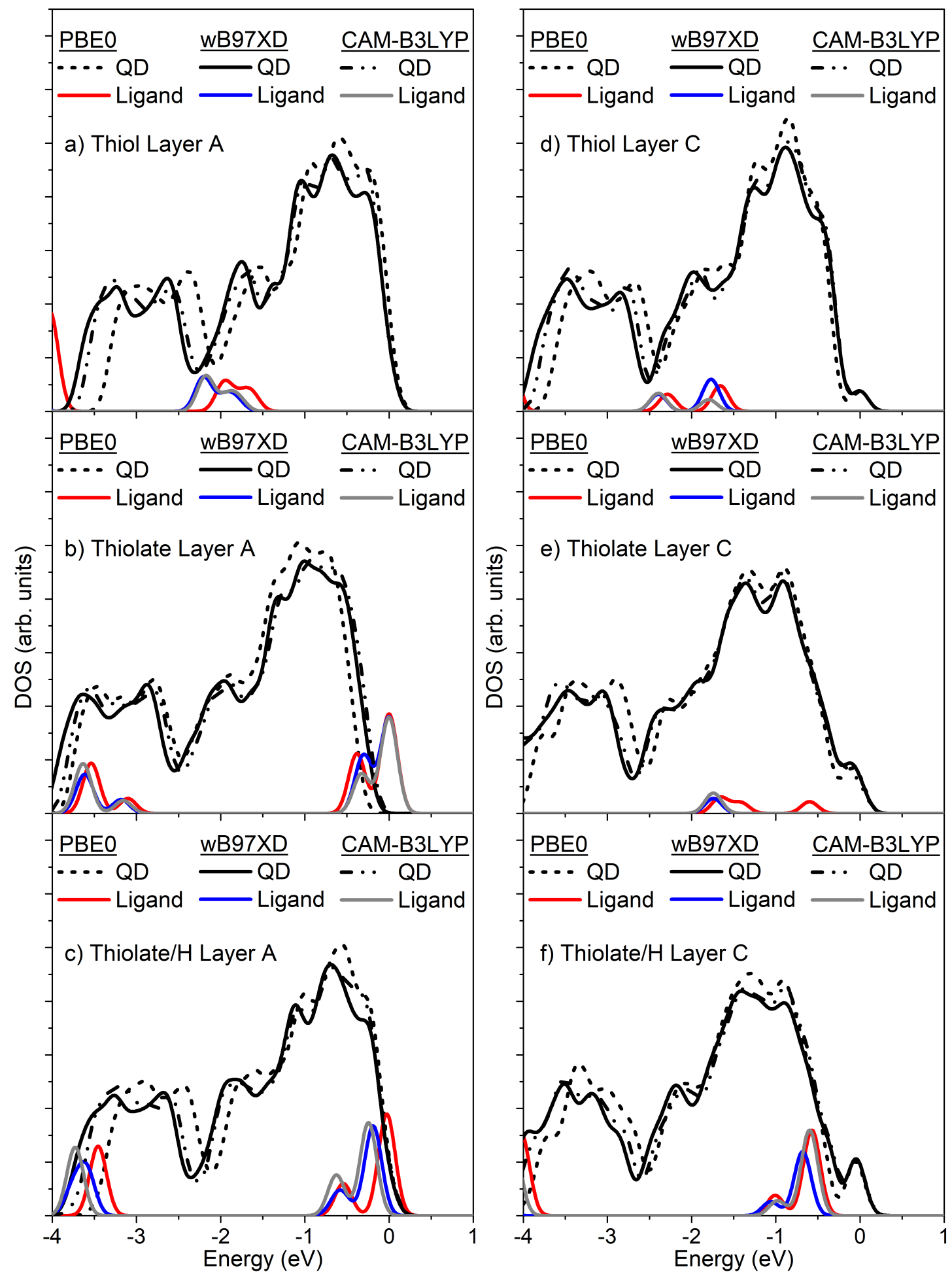

Figure S14: The projected density of states (PDOS) for bare (CdS) ${ }_{33}$ QDs with a single thiol, thiolate and thiolate/H ligand attached at the A-layer (a)-(c) and C-layer (d)-(f) computed using PBE0, wB97XD, and CAM-B3LYP with mixed basis set LANL2DZ/6-31g* in propylamine. The DOS contribution of the thiol, thiolate, and thiolate/H are multiplied by 5 for better visualization. To compare the position of the occupied ligand bands, the energies of the HOMO are set up as zero. 


\section{References:}

1. Albert, V.; Ivanov, S; Tretiak, S.; Kilina, S; Electronic structure of ligated CdSe clusters: dependence on DFT methodology. J. Phys. Chem. C 2011, 115 (32), 15793-15800.

2. Clark, T.; Chandrasekhar, J.; Spitznagel, G. W.; Schleyer, P. V. R. Efficient diffuse function-augmented basis sets for anion calculations. III. The 3-21+ G basis set for firstrow elements, Li-F. J. Comput. Chem. 1983, 4 (3), 294-301. 


\section{COORDINATES OF OPTIMIZED STRUCTURES IN ACETONITRILE}

\section{Layer A: 1 Thiolate/H with 20 methylamines}

212

$\begin{array}{lccc}\mathrm{Cd} & -2.887606 & -5.745422 & 2.074864 \\ \mathrm{~S} & -2.718499 & -5.915475 & -2.755303 \\ \mathrm{Cd} & -4.085444 & -2.271815 & -4.756416 \\ \mathrm{Cd} & -4.675322 & -4.810357 & -1.426997 \\ \mathrm{~S} & -5.123785 & -4.811309 & 1.196283 \\ \mathrm{Cd} & -5.045545 & -2.299815 & 2.269276 \\ \mathrm{~S} & -4.837792 & -2.217753 & -2.255405 \\ \mathrm{~S} & -5.016692 & -2.403030 & 4.874975 \\ \mathrm{Cd} & -6.860392 & -0.647335 & -1.322340 \\ \mathrm{~S} & -7.273928 & -1.103614 & 1.259812 \\ \mathrm{Cd} & -6.712332 & 1.226301 & 2.163601 \\ \mathrm{~S} & -6.997604 & 1.631079 & -2.533767 \\ \mathrm{Cd} & 1.760235 & -5.569569 & 1.861097 \\ \mathrm{~S} & 1.720869 & -5.616782 & -2.588375 \\ \mathrm{Cd} & -0.350918 & -1.961383 & -5.027590 \\ \mathrm{Cd} & -0.798702 & -4.626408 & -1.564351 \\ \mathrm{~S} & -0.630831 & -4.762922 & 1.183678 \\ \mathrm{Cd} & -0.531027 & -2.228993 & 2.317916 \\ \mathrm{~S} & -0.459822 & -2.077419 & -2.310906 \\ \mathrm{~S} & -0.516937 & -2.462566 & 4.949888 \\ \mathrm{~S} & -2.515844 & -0.764241 & -6.099129 \\ \mathrm{Cd} & -2.503382 & 1.624218 & -4.870847 \\ \mathrm{Cd} & -2.661801 & -0.902488 & -1.297527 \\ \mathrm{~S} & -2.749478 & -0.988777 & 1.380293 \\ \mathrm{Cd} & -2.639856 & 1.533371 & 2.443224 \\ \mathrm{~S} & -2.656647 & 1.648565 & -2.197742 \\ \mathrm{Cd} & -2.793229 & -1.130037 & 5.387913 \\ \mathrm{~S} & -2.793585 & 1.515163 & 5.072935 \\ \mathrm{Cd} & -5.005634 & 2.963110 & -1.464609 \\ \mathrm{~S} & -4.813723 & 2.780734 & 1.343852 \\ \mathrm{Cd} & -4.632490 & 5.301401 & 2.012339 \\ \mathrm{~S} & -5.019724 & 5.476425 & -2.199952 \\ \mathrm{Cd} & 3.744745 & -2.120332 & -4.834714 \\ \mathrm{Cd} & 3.976671 & -4.624576 & -1.360428 \\ \mathrm{~S} & 4.131339 & -4.752349 & 1.267237 \\ \mathrm{Cd} & 4.029927 & -2.229881 & 2.343111 \\ \mathrm{~S} & 3.872353 & -2.101201 & -2.193937 \\ \mathrm{~S} & 3.971675 & -2.345878 & 4.941018 \\ \mathrm{~S} & 1.845190 & -0.926465 & -6.111236 \\ \mathrm{Cd} & 1.648266 & 1.476526 & -4.908622 \\ \mathrm{Cd} & 1.677388 & -0.869859 & -1.199488 \\ \mathrm{~S} & 1.716838 & -0.969283 & 1.456154 \\ \mathrm{Cd} & 1.592297 & 1.586825 & 2.470223 \\ \mathrm{~S} & 1.672875 & 1.612384 & -2.223516 \\ \mathrm{Cd} & 1.731176 & -1.081171 & 5.421564 \\ \mathrm{~S} & 1.720365 & 1.560353 & 5.108118 \\ \mathrm{~S} & -0.386760 & 2.871533 & -5.955943 \\ \mathrm{Cd} & 0.057715 & 4.967431 & -4.514246\end{array}$




\begin{tabular}{lccc}
$\mathrm{Cd}$ & -0.478066 & 2.854977 & -1.192564 \\
$\mathrm{~S}$ & -0.525628 & 2.938576 & 1.469047 \\
$\mathrm{Cd}$ & -0.542385 & 5.563373 & 2.486157 \\
$\mathrm{~S}$ & -0.483033 & 5.452631 & -2.001427 \\
$\mathrm{Cd}$ & -0.545424 & 2.896570 & 5.542207 \\
$\mathrm{~S}$ & -0.546524 & 5.449864 & 5.089618 \\
$\mathrm{Cd}$ & -2.875709 & 6.456395 & -1.172635 \\
$\mathrm{~S}$ & -2.697811 & 6.893757 & 1.475319 \\
$\mathrm{Cd}$ & 5.931390 & -0.624012 & -1.245250 \\
$\mathrm{~S}$ & 6.290106 & -1.037875 & 1.365283 \\
$\mathrm{Cd}$ & 5.953267 & 1.481023 & 1.717916 \\
$\mathrm{~S}$ & 6.088015 & 1.709449 & -2.356514 \\
$\mathrm{Cd}$ & 3.979314 & 2.982886 & -1.460333 \\
$\mathrm{~S}$ & 3.742355 & 2.827373 & 1.351262 \\
$\mathrm{Cd}$ & 3.521970 & 5.340468 & 2.045253 \\
$\mathrm{~S}$ & 3.936590 & 5.484914 & -2.229741 \\
$\mathrm{Cd}$ & 1.833935 & 6.523573 & -1.138584 \\
$\mathrm{~S}$ & 1.598102 & 6.941211 & 1.496877 \\
$\mathrm{~N}$ & -4.741468 & -4.496312 & -5.287104 \\
$\mathrm{C}$ & -4.615860 & -5.003959 & -6.656337 \\
$\mathrm{H}$ & -5.698143 & -4.613486 & -4.959936 \\
$\mathrm{H}$ & -4.153684 & -5.040872 & -4.640882 \\
$\mathrm{H}$ & -3.580943 & -4.890188 & -6.988544 \\
$\mathrm{H}$ & -5.252056 & -4.418355 & -7.325056 \\
$\mathrm{H}$ & -4.895112 & -6.061250 & -6.744233 \\
$\mathrm{~N}$ & -0.405306 & -4.370009 & -5.214849 \\
$\mathrm{C}$ & -0.293174 & -4.953430 & -6.554106 \\
$\mathrm{H}$ & -1.257343 & -4.700390 & -4.751724 \\
$\mathrm{H}$ & 0.351353 & -4.719282 & -4.621918 \\
$\mathrm{H}$ & 0.647103 & -4.633160 & -7.011996 \\
$\mathrm{H}$ & -1.110942 & -4.588961 & -7.182372 \\
$\mathrm{H}$ & -0.321534 & -6.050822 & -6.548331 \\
$\mathrm{C}$ & 6.314375 & -3.637101 & -7.048118 \\
$\mathrm{H}$ & 6.381809 & -2.656043 & -7.523697 \\
$\mathrm{H}$ & 5.519935 & -4.214737 & -7.526145 \\
$\mathrm{H}$ & 7.263831 & -4.161712 & -7.180094 \\
$\mathrm{~N}$ & 5.621687 & -5.856428 & -2.621265 \\
$\mathrm{C}$ & 5.293016 & -7.244327 & -2.960584 \\
$\mathrm{H}$ & -4.593903 & 2.785871 & -5.071660 \\
$\mathrm{H}$ & 6.504117 & -5.826461 & -2.114951 \\
$\mathrm{H}$ & 5.770138 & -5.310183 & -3.476912 \\
$\mathrm{H}$ & 4.342816 & -7.263895 & -3.500601 \\
$\mathrm{H}$ & 5.172630 & -7.825666 & -2.042457 \\
$\mathrm{H}$ & 6.061826 & -7.723200 & -3.579744 \\
$\mathrm{~N}$ & 3.777686 & 2.604772 & -5.045563 \\
$\mathrm{C}$ & 4.401272 & 2.767723 & -6.361575 \\
$\mathrm{H}$ & 4.421399 & 2.118856 & -4.410035 \\
$\mathrm{H}$ & 3.641363 & 3.518216 & -4.607888 \\
& 3.735778 & 3.341172 & -7.013370 \\
$\mathrm{H}$ & 4.549651 & 1.783558 & -6.815367 \\
\hline
\end{tabular}




\begin{tabular}{|c|c|c|c|}
\hline 11 & -4.490217 & 3.660405 & -4.551407 \\
\hline $\mathrm{H}$ & -5.275088 & 2.251978 & -4.519538 \\
\hline & -5.264751 & 2.112122 & -6.942528 \\
\hline & -4.421635 & 3.666743 & -6.971635 \\
\hline & -6.097248 & 3.580036 & -6.382125 \\
\hline & 1.129761 & & .563247 \\
\hline & 1.368252 & 6.738722 & -7.008358 \\
\hline & 2.014140 & 6.963422 & -5.072898 \\
\hline & 0.582389 & 7.674633 & -5.359385 \\
\hline & 0.411481 & 6.621818 & -7.522904 \\
\hline & 1.973312 & 5.851287 & -7.209581 \\
\hline & 1.883128 & 7.617071 & -7.414950 \\
\hline & 7.643465 & -2.010023 & -2.339132 \\
\hline & 8.961924 & -1.410553 & -2.557966 \\
\hline & 7.245168 & -2.313669 & -3.232149 \\
\hline & 7.742046 & -2.8 & 2382 \\
\hline & 9.39 & -1.1 & 615 \\
\hline & 8.84 & -0.5 & 9278 \\
\hline & 9.66 & -2.0 & 793 \\
\hline & -6.764891 & -6.0 & 0040 \\
\hline & -6.639259 & -7.464 & 25449 \\
\hline & -7.320099 & -5.636428 & -2.556225 \\
\hline & -7.271508 & -5.787 & 35337 \\
\hline & -6.074177 & -7.85 & 3836 \\
\hline & -6.080567 & -7.6 & 6095 \\
\hline & -7.607685 & -7.9 & 6642 \\
\hline & -8.5 & -2 & 035 \\
\hline C & -9.93 & -1.6 & 900 \\
\hline - & -8.58 & $-2 . \varsigma$ & 849 \\
\hline-1 & -8.237834 & -2.4 & 085 \\
\hline $\mathrm{H}$ & -9.912201 & -0.7 & 7064 \\
\hline $\mathrm{H}$ & -10.286112 & -1.29 & 71763 \\
\hline $\mathrm{H}$ & -10.648597 & -2.358039 & 48637 \\
\hline & -2.401564 & 8.733660 & 5165 \\
\hline C & -3.536907 & 9.661194 & 8853 \\
\hline $\mathrm{H}$ & & & 5225 \\
\hline & -1.66 & & 646 \\
\hline - & -3.94 & $9.7^{\prime}$ & 7112 \\
\hline H & -4.31 & 9.27 & -2.5 \\
\hline $\mathrm{H}$ & -3.26 & 10.6 & 0951 \\
\hline$N$ & 2.013754 & 8.886547 & -1.740064 \\
\hline C & 3.353929 & & -1.545880 \\
\hline $\mathrm{H}$ & 1.344901 & 9.395226 & -1.166528 \\
\hline $\mathrm{H}$ & 1.718478 & 9.027550 & -2.703560 \\
\hline $\mathrm{H}$ & 4.066689 & 8.890403 & -2.158206 \\
\hline $\mathrm{H}$ & 3.641750 & 9.3274 & 97987 \\
\hline $\mathrm{H}$ & & & 06231 \\
\hline$N$ & & & 3.132689 \\
\hline C & 2.767885 & -8.652212 & 2.408244 \\
\hline $\mathrm{H}$ & 1.188720 & & 3.486076 \\
\hline 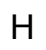 & 2.624675 & -7.313074 & 3.953642 \\
\hline & 3.726773 & -8.280085 & 2.039104 \\
\hline
\end{tabular}




\begin{tabular}{|c|c|c|c|}
\hline-1 & 2.162108 & -8.948488 & 1.548353 \\
\hline & 2.947575 & -9.534391 & 3.033802 \\
\hline & -3.186568 & -7.732017 & 3.359014 \\
\hline & -3.865133 & -8.820703 & 2.642638 \\
\hline & -3.724975 & -7.474126 & 4.183440 \\
\hline - & -2.286110 & -8.054761 & 3.706213 \\
\hline & -3.261458 & -9.113441 & 1.780261 \\
\hline - & -4.830666 & -8.461402 & 2.278137 \\
\hline - & -4.030044 & -9.701349 & 3.274029 \\
\hline V & -6.576686 & 6.278505 & 3.025931 \\
\hline & -7.119269 & 7.424650 & 2.285167 \\
\hline & -6.330408 & 6.562960 & 3.971548 \\
\hline & -7.291417 & 5.561476 & 3.127637 \\
\hline & -7.400996 & 7.100897 & 1.280135 \\
\hline $\mathrm{H}$ & -6.344063 & 8.189260 & 2.191763 \\
\hline $\mathrm{H}$ & -7.995808 & 7.867323 & 2.772675 \\
\hline $\mathrm{N}$ & -8.178353 & 1.971552 & 3.903633 \\
\hline C & -8.671224 & 0.918135 & 4.801591 \\
\hline $\mathrm{H}$ & -8.964567 & 2.448598 & 3.467480 \\
\hline $\mathrm{H}$ & -7.688693 & 2.682112 & 4.443277 \\
\hline $\mathrm{H}$ & -7.819674 & 0.417576 & 5.269731 \\
\hline 7 & -9.219217 & 0.176388 & 4.215546 \\
\hline-1 & -9.330338 & 7276 & 5.586367 \\
\hline V & 5.323851 & 041 & 0828 \\
\hline C & 5.623977 & 352 & 3.091451 \\
\hline $\mathrm{H}$ & 6.155820 & 239 & 9759 \\
\hline $\mathrm{H}$ & 5.085963 & 303 & 4.321489 \\
\hline $\mathrm{H}$ & 4.725229 & 8.254289 & 3.274439 \\
\hline $\mathrm{H}$ & 5.908580 & 7.787200 & 2.044049 \\
\hline $\mathrm{H}$ & 6.433994 & 3526 & 3.725975 \\
\hline$N$ & 7.934220 & 2.769525 & 2.095657 \\
\hline C & 9.191685 & 2.100956 & 1.736355 \\
\hline $\mathrm{H}$ & 7.954724 & 3.039747 & 3.076749 \\
\hline $\mathrm{H}$ & 7.844943 & 3.636901 & 1.570704 \\
\hline $\mathrm{H}$ & 9.167328 & 1.841848 & 0.674908 \\
\hline $\mathrm{H}$ & 9.283482 & 1.176052 & 2.310644 \\
\hline $\mathrm{H}$ & 10.071649 & 2.726141 & 1.927803 \\
\hline$N$ & -0.687436 & 2.797679 & 8.003682 \\
\hline C & 0.435533 & 3.364303 & 8.755548 \\
\hline $\mathrm{H}$ & -0.823214 & 1.825221 & 8.268673 \\
\hline $\mathrm{H}$ & -1.549063 & 3.274481 & 8.260237 \\
\hline $\mathrm{H}$ & 0.557277 & 4.414800 & 8.477655 \\
\hline $\mathrm{H}$ & 1.351751 & 2.834551 & 8.481045 \\
\hline $\mathrm{H}$ & 0.305952 & 3.302518 & 9.843717 \\
\hline $\mathrm{N}$ & 1.869688 & -1.151529 & 7.889047 \\
\hline C & 1.711318 & -2.461878 & 8.524493 \\
\hline $\mathrm{H}$ & 1.210137 & -0.489611 & 8.291480 \\
\hline $\mathrm{H}$ & 2.793177 & -0.779813 & 8.100186 \\
\hline $\mathrm{H}$ & 2.446840 & -3.151846 & 8.102304 \\
\hline $\mathrm{H}$ & 0.715178 & -2.852015 & 8.299231 \\
\hline $\mathrm{H}$ & 1.840601 & -2.435068 & 9.614249 \\
\hline $\mathrm{N}$ & -2.715667 & -1.307345 & 7.857458 \\
\hline
\end{tabular}




$\begin{array}{rrrr}\mathrm{C} & -3.714745 & -0.542824 & 8.608104 \\ \mathrm{H} & -1.780288 & -1.049317 & 8.162208 \\ \mathrm{H} & -2.809057 & -2.297900 & 8.070798 \\ \mathrm{H} & -4.713718 & -0.857729 & 8.293894 \\ \mathrm{H} & -3.606302 & 0.518512 & 8.368870 \\ \mathrm{H} & -3.634001 & -0.669575 & 9.695480 \\ \mathrm{~S} & 5.979694 & -3.453691 & -5.211208 \\ \mathrm{H} & 1.701932 & -6.949784 & -2.240907\end{array}$

\section{Layer C: 1 Thiolate/H with 20 methylamines}

212

$\begin{array}{lccc}\mathrm{Cd} & -2.615998 & -5.806951 & 2.083571 \\ \mathrm{~S} & -2.349304 & -5.964680 & -2.621007 \\ \mathrm{Cd} & -4.159063 & -2.243999 & -4.753005 \\ \mathrm{Cd} & -4.254070 & -4.831658 & -1.325403 \\ \mathrm{~S} & -4.866255 & -4.809210 & 1.268127 \\ \mathrm{Cd} & -4.452783 & -2.517876 & 2.569468 \\ \mathrm{~S} & -4.598450 & -2.247341 & -2.180735 \\ \mathrm{~S} & -4.801109 & -2.391487 & 5.096761 \\ \mathrm{Cd} & -6.685971 & -0.658329 & -1.628325 \\ \mathrm{~S} & -6.858105 & -0.811237 & 1.269476 \\ \mathrm{Cd} & -6.878974 & 1.763957 & 2.045545 \\ \mathrm{~S} & -6.874556 & 1.730021 & -2.486891 \\ \mathrm{Cd} & 1.921243 & -5.838305 & 1.897880 \\ \mathrm{~S} & 1.958714 & -5.985721 & -2.559689 \\ \mathrm{Cd} & -0.132183 & -2.107615 & -4.907892 \\ \mathrm{Cd} & -0.202807 & -4.890368 & -1.541190 \\ \mathrm{~S} & -0.362535 & -4.775019 & 1.250829 \\ \mathrm{Cd} & -0.266315 & -2.284162 & 2.404999 \\ \mathrm{~S} & -0.187663 & -2.219191 & -2.213560 \\ \mathrm{~S} & -0.308139 & -2.460586 & 5.035843 \\ \mathrm{~S} & -2.304994 & -1.027594 & -6.053550 \\ \mathrm{Cd} & -2.277591 & 1.391771 & -4.897834 \\ \mathrm{Cd} & -2.372609 & -1.008942 & -1.199335 \\ \mathrm{~S} & -2.475159 & -1.035539 & 1.459590 \\ \mathrm{Cd} & -2.427102 & 1.547901 & 2.433926 \\ \mathrm{~S} & -2.400438 & 1.479477 & -2.222312 \\ \mathrm{Cd} & -2.562537 & -1.083046 & 5.509592 \\ \mathrm{~S} & -2.575373 & 1.536744 & 5.066973 \\ \mathrm{Cd} & -4.687272 & 2.901229 & -1.552595 \\ \mathrm{~S} & -4.577642 & 2.723813 & 1.212689 \\ \mathrm{Cd} & -4.404119 & 5.182433 & 2.063166 \\ \mathrm{~S} & -4.475708 & 5.287762 & -2.606269 \\ \mathrm{Cd} & 3.861719 & -2.243519 & -4.685474 \\ \mathrm{Cd} & 3.855948 & -4.827898 & -1.264291 \\ \mathrm{~S} & 4.231703 & -4.885090 & 1.376019 \\ \mathrm{Cd} & 4.172647 & -2.333664 & 2.425658 \\ \mathrm{~S} & 4.269451 & -2.251906 & -2.118241 \\ \mathrm{~S} & 4.174470 & -2.427490 & 5.023776 \\ \mathrm{~S} & 2.036720 & -0.948487 & -5.969051 \\ & & & \end{array}$




\begin{tabular}{lccc}
$\mathrm{Cd}$ & 1.970872 & 1.456882 & -4.792053 \\
$\mathrm{Cd}$ & 2.008328 & -0.989416 & -1.230881 \\
$\mathrm{~S}$ & 1.943763 & -1.045870 & 1.449148 \\
$\mathrm{Cd}$ & 1.882492 & 1.535487 & 2.446529 \\
$\mathrm{~S}$ & 2.000702 & 1.573324 & -2.107451 \\
$\mathrm{Cd}$ & 1.955159 & -1.115669 & 5.468278 \\
$\mathrm{~S}$ & 1.975795 & 1.515585 & 5.091483 \\
$\mathrm{~S}$ & -0.139385 & 2.644720 & -5.931400 \\
$\mathrm{Cd}$ & -0.515751 & 4.756209 & -4.522631 \\
$\mathrm{Cd}$ & -0.249605 & 2.743249 & -1.201053 \\
$\mathrm{~S}$ & -0.276271 & 2.867983 & 1.458294 \\
$\mathrm{Cd}$ & -0.342672 & 5.502855 & 2.454873 \\
$\mathrm{~S}$ & -0.239434 & 5.345739 & -2.012685 \\
$\mathrm{Cd}$ & -0.292344 & 2.856343 & 5.510447 \\
$\mathrm{~S}$ & -0.301965 & 5.409371 & 5.055905 \\
$\mathrm{Cd}$ & -2.603265 & 6.396492 & -1.203055 \\
$\mathrm{~S}$ & -2.515158 & 6.794805 & 1.422907 \\
$\mathrm{Cd}$ & 6.241992 & -0.645599 & -1.162018 \\
$\mathrm{~S}$ & 6.420843 & -1.151018 & 1.442494 \\
$\mathrm{Cd}$ & 6.094748 & 1.264915 & 2.214364 \\
$\mathrm{~S}$ & 6.378645 & 1.633626 & -2.368967 \\
$\mathrm{Cd}$ & 4.325981 & 2.934234 & -1.367200 \\
$\mathrm{~S}$ & 4.122736 & 2.778345 & 1.442824 \\
$\mathrm{Cd}$ & 3.604217 & 5.229011 & 2.190228 \\
$\mathrm{~S}$ & 4.257665 & 5.425483 & -2.166073 \\
$\mathrm{Cd}$ & 2.104432 & 6.387094 & -1.135530 \\
$\mathrm{~S}$ & 1.783691 & 6.888688 & 1.459609 \\
$\mathrm{~N}$ & -5.750970 & -3.514285 & -6.034728 \\
$\mathrm{C}$ & -5.157163 & -4.510582 & -6.935999 \\
$\mathrm{H}$ & -6.316555 & -2.858314 & -6.569096 \\
$\mathrm{H}$ & -6.390715 & -3.970905 & -5.388444 \\
$\mathrm{H}$ & -4.574467 & -5.223581 & -6.347325 \\
$\mathrm{H}$ & -4.479563 & -4.006665 & -7.629682 \\
$\mathrm{H}$ & -5.909450 & -5.060516 & -7.513499 \\
$\mathrm{~N}$ & -0.125093 & -4.506105 & -5.122891 \\
$\mathrm{C}$ & -0.106073 & -5.087332 & -6.466790 \\
$\mathrm{H}$ & -0.945199 & -4.841327 & -4.605441 \\
$\mathrm{H}$ & 0.669105 & -4.854677 & -4.573877 \\
$\mathrm{H}$ & 0.787626 & -4.749216 & -6.999823 \\
$\mathrm{H}$ & -0.980134 & -4.742338 & -7.027172 \\
$\mathrm{H}$ & -0.110221 & -6.185395 & -6.459700 \\
$\mathrm{~N}$ & 5.140438 & -3.841497 & -5.954912 \\
$\mathrm{C}$ & 4.603853 & -4.155976 & -7.285015 \\
$\mathrm{H}$ & 5.209319 & -4.691930 & -5.400050 \\
$\mathrm{H}$ & 6.091088 & -3.488348 & -6.040063 \\
$\mathrm{H}$ & 4.539457 & -3.237298 & -7.872908 \\
$\mathrm{H}$ & 3.595152 & -4.562266 & -7.177565 \\
$\mathrm{H}$ & 5.220232 & -4.881790 & -7.828427 \\
& 6.4762298 & -5.739932 & -1.842363 \\
& & -158310 & -2.209700 \\
\hline
\end{tabular}




\begin{tabular}{|c|c|c|c|}
\hline t & 5.489577 & -7.318112 & -3.100890 \\
\hline & 5.675326 & -7.751005 & -1.396153 \\
\hline & 117763 & -7.521 & .411669 \\
\hline & 4.030562 & 2.6716 & -4.960596 \\
\hline & 4.595535 & 2.929379 & -6.287940 \\
\hline & 4.713786 & & -4.377880 \\
\hline & 3.885910 & 3.554302 & -4.463573 \\
\hline & 3.881246 & 3.503855 & -6.884499 \\
\hline & 4.771224 & 1.977845 & -6.797843 \\
\hline & 5.542383 & 3.483447 & -6.249917 \\
\hline & -4.325438 & 2.6 & -5.164251 \\
\hline & -4.804747 & 2.8 & 20408 \\
\hline & 1569 & 3.4 & 5428 \\
\hline & -5.0 & 2.1 & 2790 \\
\hline & -4.9 & & 2302 \\
\hline & -4.045608 & & 164 \\
\hline & -5.742640 & & 481 \\
\hline & -1.579730 & & 7909 \\
\hline & -1.741801 & & 16184 \\
\hline & -1.078501 & & 33007 \\
\hline & -2.491070 & & 4610 \\
\hline & -2.289716 & & 5894 \\
\hline & -0.7562 & & 151 \\
\hline & -2.2 & & 892 \\
\hline & 8.15 & -2. & 370 \\
\hline & 9.46 & -1.3 & 277 \\
\hline & 8.043476 & & 3493 \\
\hline & 8.111101 & -2.8 & 7250 \\
\hline & 9.585378 & & 7125 \\
\hline - & 9.511338 & -0.4 & 7197 \\
\hline H & 10.306056 & & 8946 \\
\hline v & -6.241592 & -6.1 & 9649 \\
\hline & -6.124769 & -7.5 & 1168 \\
\hline & -6.4 & -6.0 & 2658 \\
\hline & -7.0 & -5.7 & 7176 \\
\hline$H$ & -5.9 & -7.7 & 021 \\
\hline $\mathrm{H}$ & & & 3396 \\
\hline $\mathrm{H}$ & -7.033907 & -8.1 & 93585 \\
\hline J & -8.409526 & -2.2 & -2.360515 \\
\hline C & -9.794946 & -1.74 & -2.209640 \\
\hline $\mathrm{H}$ & -8.278161 & -3.08 & -1.858951 \\
\hline $\mathrm{H}$ & -8.216529 & -2.41 & 37659 \\
\hline t & -9.92 & -0.8 & 7710 \\
\hline$y$ & -9.9928 & -1.5 & 2602 \\
\hline $\mathrm{H}$ & -10.529763 & -2.4 & 76648 \\
\hline & -2.616766 & 8.76 & -1.840646 \\
\hline C & -3.923281 & 9.42 & -1.723711 \\
\hline $\mathrm{H}$ & -2.257805 & 8.881060 & -2.785604 \\
\hline $\mathrm{H}$ & -1.947733 & 9.230567 & -1.230596 \\
\hline $\mathrm{H}$ & -4.287522 & 9.309700 & -0.698860 \\
\hline $\mathrm{H}$ & -4.633656 & 8.927401 & -2.391382 \\
\hline & -3.892663 & 10.490193 & -1.970378 \\
\hline
\end{tabular}




\begin{tabular}{cccc}
$\mathrm{N}$ & 1.967522 & 8.622762 & -2.134691 \\
$\mathrm{C}$ & 3.034456 & 9.553096 & -1.752534 \\
$\mathrm{H}$ & 1.062198 & 9.025049 & -1.902658 \\
$\mathrm{H}$ & 1.964098 & 8.500199 & -3.144936 \\
$\mathrm{H}$ & 4.000698 & 9.119632 & -2.023846 \\
$\mathrm{H}$ & 3.017521 & 9.690230 & -0.668069 \\
$\mathrm{H}$ & 2.942906 & 10.535565 & -2.232416 \\
$\mathrm{~N}$ & 1.775513 & -8.152828 & 2.503041 \\
$\mathrm{C}$ & 2.509489 & -9.050328 & 1.600614 \\
$\mathrm{H}$ & 0.793575 & -8.418664 & 2.531681 \\
$\mathrm{H}$ & 2.120940 & -8.260794 & 3.454223 \\
$\mathrm{H}$ & 3.563858 & -8.763037 & 1.590556 \\
$\mathrm{H}$ & 2.116793 & -8.938634 & 0.586769 \\
$\mathrm{H}$ & 2.432461 & -10.103267 & 1.895969 \\
$\mathrm{~N}$ & -2.897043 & -7.829448 & 3.319016 \\
$\mathrm{C}$ & -3.165266 & -9.010784 & 2.488025 \\
$\mathrm{H}$ & -3.667490 & -7.680635 & 3.967208 \\
$\mathrm{H}$ & -2.075355 & -7.992015 & 3.896909 \\
$\mathrm{H}$ & -2.317419 & -9.178825 & 1.819444 \\
$\mathrm{H}$ & -4.051548 & -8.824602 & 1.876303 \\
$\mathrm{H}$ & -3.330468 & -9.916289 & 3.083181 \\
$\mathrm{~N}$ & -6.114356 & 5.842313 & 3.573697 \\
$\mathrm{C}$ & -6.749642 & 7.133279 & 3.283236 \\
$\mathrm{H}$ & -5.715940 & 5.858964 & 4.510428 \\
$\mathrm{H}$ & -6.823799 & 5.098074 & 3.578552 \\
$\mathrm{H}$ & -7.201028 & 7.095148 & 2.288411 \\
$\mathrm{H}$ & -1.334211 & 3.211736 & 8.209625 \\
$\mathrm{H}$ & -5.993071 & 7.922294 & 3.283820 \\
$\mathrm{H}$ & -7.528771 & 7.392739 & 4.010327 \\
$\mathrm{C}$ & -9.550721 & 4.045182 & 1.944907 \\
$\mathrm{H}$ & -10.094714 & 3.279149 & 1.388093 \\
$\mathrm{H}$ & -8.887446 & 4.583864 & 1.263978 \\
$\mathrm{H}$ & -10.267989 & 4.749231 & 2.373381 \\
$\mathrm{~N}$ & 5.231795 & 6.444830 & 3.487946 \\
$\mathrm{C}$ & 5.875098 & 7.528901 & 2.735083 \\
$\mathrm{H}$ & 5.937069 & 5.808669 & 3.852593 \\
$\mathrm{H}$ & 4.752444 & 6.825390 & 4.301046 \\
$\mathrm{H}$ & 5.105612 & 8.205503 & 2.355027 \\
$\mathrm{H}$ & 6.408183 & 7.104661 & 1.880561 \\
$\mathrm{H}$ & 6.583752 & 8.104752 & 3.342070 \\
$\mathrm{~N}$ & 7.973639 & 2.307829 & 3.266366 \\
$\mathrm{C}$ & 9.230808 & 2.209396 & 2.513221 \\
$\mathrm{H}$ & 8.087821 & 1.883329 & 4.184395 \\
$\mathrm{H}$ & 9.750238 & 3.285335 & 3.439227 \\
$\mathrm{H}$ & -106287 & 2.696353 & 1.542940 \\
$\mathrm{H}$ & 2.843081 & 8.493388 \\
\hline
\end{tabular}




$\begin{array}{rrrr}\mathrm{H} & 0.484730 & 3.290600 & 9.829901 \\ \mathrm{~N} & 2.110276 & -1.168089 & 7.933046 \\ \mathrm{C} & 1.845359 & -2.454655 & 8.581732 \\ \mathrm{H} & 1.516012 & -0.448183 & 8.337726 \\ \mathrm{H} & 3.065454 & -0.877999 & 8.130428 \\ \mathrm{H} & 2.521355 & -3.207284 & 8.167162 \\ \mathrm{H} & 0.820878 & -2.764981 & 8.359663 \\ \mathrm{H} & 1.977519 & -2.427553 & 9.671139 \\ \mathrm{~N} & -2.456429 & -1.270251 & 7.981118 \\ \mathrm{C} & -3.450698 & -0.527566 & 8.760334 \\ \mathrm{H} & -1.519460 & -1.026266 & 8.292519 \\ \mathrm{H} & -2.553519 & -2.266708 & 8.163467 \\ \mathrm{H} & -4.451747 & -0.817918 & 8.430049 \\ \mathrm{H} & -3.330633 & 0.542359 & 8.569718 \\ \mathrm{H} & -3.374622 & -0.701615 & 9.841398 \\ \mathrm{~S} & -8.572841 & 3.270026 & 3.352480 \\ \mathrm{H} & -8.121219 & -1.271344 & 1.564751\end{array}$

Fully passivated with thiols

192

$\begin{array}{lccc}\text { Cd } & -2.338768 & -5.292471 & 1.956736 \\ \mathrm{~S} & -2.399246 & -6.275127 & -2.296370 \\ \mathrm{Cd} & -4.783193 & -0.151302 & -4.361410 \\ \mathrm{Cd} & -4.344837 & -4.612000 & -1.308758 \\ \mathrm{~S} & -4.790943 & -5.043272 & 1.246978 \\ \mathrm{Cd} & -4.781066 & -2.475536 & 1.938256 \\ \mathrm{~S} & -4.745731 & -2.325909 & -2.565935 \\ \mathrm{~S} & -4.951535 & -1.395700 & 4.495442 \\ \mathrm{Cd} & -6.379245 & -0.676218 & -1.157960 \\ \mathrm{~S} & -7.143452 & -1.227576 & 1.229851 \\ \mathrm{Cd} & -5.762021 & 0.461359 & 2.783969 \\ \mathrm{~S} & -6.494247 & 1.254576 & -2.942179 \\ \mathrm{Cd} & 2.223685 & -5.377443 & 2.242194 \\ \mathrm{~S} & 1.935725 & -5.592076 & -3.256054 \\ \mathrm{Cd} & -1.069039 & -2.072764 & -5.261866 \\ \mathrm{Cd} & -0.144651 & -4.791873 & -1.819030 \\ \mathrm{~S} & -0.024855 & -4.925895 & 0.900247 \\ \mathrm{Cd} & -0.110818 & -2.290089 & 1.898284 \\ \mathrm{~S} & -0.484419 & -2.235784 & -2.576098 \\ \mathrm{~S} & -0.218033 & -2.375440 & 4.576064 \\ \mathrm{~S} & -2.892616 & -0.310169 & -6.139236 \\ \mathrm{Cd} & -2.080664 & 2.041208 & -5.119715 \\ \mathrm{Cd} & -2.579594 & -0.963383 & -1.555587 \\ \mathrm{~S} & -2.451152 & -1.147173 & 1.139961 \\ \mathrm{Cd} & -2.255898 & 1.389437 & 2.144967 \\ \mathrm{~S} & -2.450998 & 1.594717 & -2.345958 \\ \mathrm{Cd} & -2.418141 & -0.940401 & 4.874804 \\ \mathrm{~S} & -2.172356 & 1.715669 & 4.826895 \\ \mathrm{Cd} & -4.757586 & 2.620081 & -1.427412\end{array}$




\begin{tabular}{|c|c|c|c|}
\hline & -4.700301 & 2.467153 & \\
\hline & -3.704165 & 4.713076 & 2.174235 \\
\hline & -4.85 & & \\
\hline & & & 9618 \\
\hline & 689738 & 448 & 93926 \\
\hline & 4.466874 & -5.003097 & \\
\hline & 4.416849 & -2.427697 & 1.688610 \\
\hline & 4.181845 & -2.414314 & -2.793220 \\
\hline & 4.223146 & -2.567365 & 4.479752 \\
\hline & 1.385181 & -1.615 & -6.268312 \\
\hline & & & \\
\hline & & & -1.806457 \\
\hline & 2.09 & $-1.0 \varsigma$ & \\
\hline & & & \\
\hline & 1.86 & 1.3 & -2.6 \\
\hline & & & \\
\hline & 2.45 & & \\
\hline & 0.28 & 2.78 & 3599 \\
\hline & & & -4.447208 \\
\hline & & & \\
\hline & -0.16 & & \\
\hline & -0.0 & & 29576 \\
\hline & -0.25 & 5.30 & 2822 \\
\hline & & & \\
\hline & 0.2 & 5.4 & \\
\hline & & & 249 \\
\hline & $-2.3 \varepsilon$ & & \\
\hline & & & -1.676865 \\
\hline & & 11 & \\
\hline & & & \\
\hline & & & \\
\hline & & & 27936 \\
\hline & 4.1 & 2.96 & $0.7^{1}$ \\
\hline & & & \\
\hline & 3.6 & 5.1 & 63 \\
\hline & & & 786 \\
\hline & & & \\
\hline & & & \\
\hline C & & & \\
\hline $\mathrm{H}$ & -4.00 & 4.86 & -5.788473 \\
\hline $\mathrm{H}$ & & 95 & -7.782543 \\
\hline & & 9 & \\
\hline & & 0 & 2503 \\
\hline & & -4.6 & \\
\hline C & & & \\
\hline & & & \\
\hline 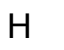 & & & \\
\hline $\mathrm{H}$ & & 82 & -8.070645 \\
\hline $\mathrm{H}$ & & & -8.021412 \\
\hline$S$ & & 89 & -7.271741 \\
\hline C & 5.157081 & -3.518346 & -7.435635 \\
\hline $\mathrm{H}$ & 3.278642 & -5.075240 & -7.049634 \\
\hline
\end{tabular}




\begin{tabular}{|c|c|c|c|}
\hline H & 6.235790 & -3.550158 & -7.593111 \\
\hline & 4.928755 & -2.972169 & -6.519475 \\
\hline & 667481 & -3.057190 & -8.293754 \\
\hline & 6.171098 & -6.589690 & -3.896976 \\
\hline & 5.074715 & -8.102231 & -3.919441 \\
\hline & 5.643573 & -5.970026 & -5.017637 \\
\hline & 4.029793 & -7.800731 & -3.822993 \\
\hline & 5.370051 & -8.704758 & -3.059318 \\
\hline & 5.235257 & -8.668709 & -4.838047 \\
\hline & 4.537356 & 0.990353 & -6.194679 \\
\hline & 4.826864 & 2.783610 & -6.669487 \\
\hline & 5.612247 & 1.259469 & -4.246686 \\
\hline & 4.765257 & 3.428168 & -5.7 \\
\hline & 4.081 & 3.10 & -7.4 \\
\hline & 5.82 & & -7.1 \\
\hline 5 & -3.956 & & 104 \\
\hline C & -3.34 & & -6.8 \\
\hline & -4.532941 & 5.026 & -3.38 \\
\hline & -2.974187 & & -7.645431 \\
\hline & -2.553204 & & -6.450718 \\
\hline & -4.183667 & & \\
\hline & -0.623323 & & -5.0 \\
\hline C & 0.465 & & -6.4 \\
\hline & -0.5 & & -4 \\
\hline & 1.46 & & -6 . \\
\hline $\mathrm{H}$ & 0.52 & & 351 \\
\hline $\mathrm{H}$ & 0.01 & & 234 \\
\hline$S$ & 7.744551 & 822 & 695 \\
\hline C & 7.976100 & & -5.1 \\
\hline $\mathrm{H}$ & 6.405586 & -2.823 & -3.7 \\
\hline $\mathrm{H}$ & 9.024440 & & -5.482408 \\
\hline - & 7.753757 & & 4182 \\
\hline & 870 & & 4724 \\
\hline 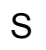 & -6.75 & -6.2 & -2.6 \\
\hline C & -5.97 & -7.9 & -2.6 \\
\hline $\mathrm{H}$ & -6.276743 & -5.86 & 4503 \\
\hline $\mathrm{H}$ & -6.275429 & & -1.729830 \\
\hline $\mathrm{H}$ & -4.884212 & -7.903037 & -2.697483 \\
\hline $\mathrm{H}$ & -6.344206 & -8.572679 & -3.510310 \\
\hline S & -8.365927 & -2.851502 & -3.693284 \\
\hline C & -8.179723 & -2.006326 & -5.348181 \\
\hline $\mathrm{H}$ & -7.030848 & -2.774851 & -3.296918 \\
\hline $\mathrm{H}$ & -7.811484 & -0.988181 & -5.208070 \\
\hline $\mathrm{H}$ & -9.174632 & -1.980378 & -5.794794 \\
\hline $\mathrm{H}$ & -7.502727 & -2.578976 & -5.984452 \\
\hline S & -2.461271 & 9.187563 & -2.003467 \\
\hline C & -4.147238 & 9.612648 & -1.318965 \\
\hline $\mathrm{H}$ & -2.781555 & 9.175764 & -3.339649 \\
\hline $\mathrm{H}$ & -4.033120 & 9.611779 & -0.234580 \\
\hline $\mathrm{H}$ & -4.871933 & 8.854714 & -1.618083 \\
\hline $\mathrm{H}$ & -4.446506 & 10.602164 & -1.665017 \\
\hline & 2.050388 & 9.271324 & -2.654772 \\
\hline
\end{tabular}




\begin{tabular}{|c|c|c|c|}
\hline C & 3.533438 & 9.181098 & -3.788058 \\
\hline 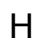 & 1.073298 & 8.897569 & -3.574144 \\
\hline & 3.711149 & 8.144460 & -4.080763 \\
\hline & 4.380019 & 9.553839 & -3.210017 \\
\hline & 3.373341 & 9.817775 & -4.659160 \\
\hline S & 2.361614 & -6.042921 & 4.771879 \\
\hline C & 4.064290 & -6.832113 & 4.871925 \\
\hline $\mathrm{H}$ & 3.573257 & -3.796666 & 4.605155 \\
\hline $\mathrm{H}$ & 4.834325 & -6.122034 & 4.559519 \\
\hline $\mathrm{H}$ & 4.116155 & -7.721139 & 4.239486 \\
\hline - & 4.248166 & -7.122546 & 5.909116 \\
\hline 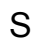 & -2.389925 & -5.171742 & 4.965712 \\
\hline U & -1.357786 & -6.554937 & 5.681857 \\
\hline $\mathrm{H}$ & -1.424550 & -4.123768 & 4.958876 \\
\hline $\mathrm{H}$ & -0.380527 & -6.590984 & 5.196676 \\
\hline $\mathrm{H}$ & -1.905714 & 0384 & 5.501123 \\
\hline $\mathrm{H}$ & -1.243267 & -6.395146 & 6.754805 \\
\hline$S$ & -3.643249 & 5.494005 & 5.190683 \\
\hline C & -3.763621 & 7.353212 & 5.041181 \\
\hline $\mathrm{H}$ & -2.265305 & 5.398495 & 5.240975 \\
\hline $\mathrm{H}$ & -4.828764 & 7.585224 & 5.010569 \\
\hline-1 & -3.280820 & 7.675401 & 4.116858 \\
\hline$\dashv$ & -3.305454 & 7.8 & 5.913407 \\
\hline$S$ & -8.000103 & 2.02 & 4.671251 \\
\hline C & -8.808193 & 478 & 5.341824 \\
\hline $\mathrm{H}$ & -8.912390 & 361 & 3.685086 \\
\hline $\mathrm{H}$ & -8.141791 & 0.115452 & 6.122916 \\
\hline $\mathrm{H}$ & -8.898943 & -0.263742 & 4.551875 \\
\hline $\mathrm{H}$ & -9.783047 & 0.726811 & 5.764404 \\
\hline S & 4.010363 & 5.794967 & 4.643386 \\
\hline C & 3.858676 & 7.666251 & 4.576250 \\
\hline $\mathrm{H}$ & 1.605159 & 5.627368 & 4.744025 \\
\hline-1 & 3.069467 & 6995 & 3.878647 \\
\hline $\mathrm{H}$ & 4.803798 & 2094 & 4.257413 \\
\hline $\mathrm{H}$ & 3.612622 & 0103 & 5.576795 \\
\hline$S$ & 6.028787 & 1.181176 & 4.542822 \\
\hline C & 6.604493 & 5279 & 5.110570 \\
\hline $\mathrm{H}$ & 4.621716 & 1.379460 & 4.631741 \\
\hline $\mathrm{H}$ & 6.079721 & 3.651143 & 4.564892 \\
\hline $\mathrm{H}$ & 7.674882 & 2.914581 & 4.907804 \\
\hline $\mathrm{H}$ & 6.425022 & 2.964184 & 6.181865 \\
\hline $\mathrm{S}$ & -1.691060 & 1.458743 & 8.488676 \\
\hline C & -1.090854 & 3.220808 & 8.631948 \\
\hline $\mathrm{H}$ & -1.913712 & 1.456628 & 7.100601 \\
\hline $\mathrm{H}$ & -0.181580 & 3.358161 & 8.043869 \\
\hline $\mathrm{H}$ & -0.876802 & 3.393152 & 9.687395 \\
\hline $\mathrm{H}$ & -1.869299 & 3.907127 & 8.295073 \\
\hline$S$ & 1.632093 & -0.441471 & 8.563451 \\
\hline C & 0.888144 & -2.102744 & 8.981201 \\
\hline $\mathrm{H}$ & 0.445957 & 0.286242 & 8.501116 \\
\hline $\mathrm{H}$ & 1.722801 & -2.800985 & 9.055937 \\
\hline $\mathrm{H}$ & 0.210126 & -2.422413 & 8.188244 \\
\hline
\end{tabular}




$\begin{array}{lrrr}\mathrm{H} & 0.364645 & -2.050702 & 9.937029 \\ \mathrm{~S} & -3.288304 & -2.370107 & 8.362079 \\ \mathrm{C} & -4.715321 & -1.173981 & 8.514119 \\ \mathrm{H} & -2.723218 & -2.156986 & 9.596811 \\ \mathrm{H} & -5.195290 & -1.175815 & 7.533194 \\ \mathrm{H} & -4.337551 & -0.176218 & 8.742693 \\ \mathrm{H} & -5.411872 & -1.514478 & 9.281303\end{array}$

\section{Fully passivated with thiolate/H}

192

$\begin{array}{lccc}\text { Cd } & -1.524839 & -5.803910 & 2.088915 \\ \text { S } & -1.668684 & -6.508678 & -3.349771 \\ \text { Cd } & -5.005025 & -1.682995 & -5.806030 \\ \text { Cd } & -4.052294 & -5.257385 & -3.073046 \\ \text { S } & -3.756809 & -5.345799 & 0.675939 \\ \text { Cd } & -4.314415 & -2.756952 & 1.518672 \\ \text { S } & -4.403442 & -2.628572 & -3.417328 \\ \text { S } & -4.715901 & -2.737820 & 4.152424 \\ \text { Cd } & -6.852536 & -1.942646 & -2.627969 \\ \text { S } & -6.490390 & -1.700514 & 0.176018 \\ \text { Cd } & -6.437734 & 0.588622 & 1.848237 \\ \text { S } & -6.263830 & 0.596921 & -3.798580 \\ \text { Cd } & 2.482889 & -6.123047 & 1.487380 \\ \text { S } & 2.607276 & -5.132421 & -3.970054 \\ \text { Cd } & -0.573323 & -2.577296 & -5.780185 \\ \text { Cd } & 0.233915 & -4.860604 & -2.328143 \\ \text { S } & 0.361197 & -5.003362 & 0.393750 \\ \text { Cd } & -0.061019 & -2.430494 & 1.230259 \\ \text { S } & -0.128596 & -2.329254 & -3.139941 \\ \text { S } & -0.277187 & -2.182089 & 4.046456 \\ \text { S } & -2.512821 & -0.662376 & -6.569879 \\ \text { Cd } & -2.460181 & 1.974109 & -5.710071 \\ \text { Cd } & -2.412826 & -1.186489 & -2.304722 \\ \text { S } & -2.361197 & -1.348182 & 0.406991 \\ \text { Cd } & -2.472954 & 1.202764 & 1.162327 \\ \text { S } & -2.417475 & 1.393057 & -3.095045 \\ \text { Cd } & -2.648192 & -1.344560 & 5.359369 \\ \text { S } & -2.335022 & 1.109636 & 4.128302 \\ \text { Cd } & -4.772995 & 2.321436 & -2.232519 \\ \text { S } & -4.893161 & 2.219387 & 0.488746 \\ \text { Cd } & -5.076313 & 4.594015 & 1.668372 \\ \text { S } & -5.169129 & 4.883120 & -3.048658 \\ \text { Cd } & 3.662869 & -3.107460 & -5.671133 \\ \text { Cd } & 5.106572 & -4.525593 & -2.684924 \\ \text { S } & 4.535487 & -4.788895 & 0.136063 \\ \text { Cd } & 4.247791 & -2.277314 & 1.277285 \\ \text { S } & 4.392334 & -2.028130 & -3.283011 \\ \text { S } & 4.185235 & -2.936351 & 3.879301 \\ \text { S } & 1.824514 & -1.256917 & -6.549632 \\ \text { Cd } & 2.354515 & 1.370942 & -5.728186 \\ \text { Cd } & 2.091792 & -0.965745 & -2.406252 \\ & & & \end{array}$




\begin{tabular}{lccc}
$\mathrm{S}$ & 2.060954 & -1.110201 & 0.306245 \\
$\mathrm{Cd}$ & 1.962150 & 1.429602 & 1.092449 \\
$\mathrm{~S}$ & 1.880088 & 1.599678 & -3.082039 \\
$\mathrm{Cd}$ & 2.177400 & -1.412782 & 5.077196 \\
$\mathrm{~S}$ & 2.002232 & 1.170383 & 3.968488 \\
$\mathrm{~S}$ & 0.152525 & 2.913269 & -6.347752 \\
$\mathrm{Cd}$ & 0.914275 & 5.385685 & -5.298682 \\
$\mathrm{Cd}$ & -0.356208 & 2.807407 & -2.102900 \\
$\mathrm{~S}$ & -0.331256 & 2.709993 & 0.586792 \\
$\mathrm{Cd}$ & -0.459015 & 5.122711 & 1.704909 \\
$\mathrm{~S}$ & -0.514020 & 5.389802 & -3.032189 \\
$\mathrm{Cd}$ & -0.125952 & 2.452364 & 5.344669 \\
$\mathrm{~S}$ & -0.320286 & 5.099123 & 4.379848 \\
$\mathrm{Cd}$ & -2.939573 & 6.350077 & -2.459862 \\
$\mathrm{~S}$ & -2.915281 & 5.868561 & 0.618039 \\
$\mathrm{Cd}$ & 6.525277 & -0.520026 & -2.698400 \\
$\mathrm{~S}$ & 6.220807 & -0.517165 & 0.473298 \\
$\mathrm{Cd}$ & 5.706040 & 1.601565 & 2.111508 \\
$\mathrm{~S}$ & 6.369176 & 2.155527 & -3.175121 \\
$\mathrm{Cd}$ & 3.980531 & 2.937019 & -2.152055 \\
$\mathrm{~S}$ & 4.089664 & 3.008360 & 0.539065 \\
$\mathrm{Cd}$ & 3.755635 & 5.251177 & 1.871520 \\
$\mathrm{~S}$ & 3.163558 & 5.314510 & -3.481606 \\
$\mathrm{Cd}$ & 1.340098 & 7.100129 & -2.181482 \\
$\mathrm{~S}$ & 1.608152 & 6.654044 & 0.612828 \\
$\mathrm{~S}$ & -6.712439 & -2.418653 & -7.598477 \\
$\mathrm{C}$ & -8.280714 & -1.514564 & -7.089657 \\
$\mathrm{H}$ & -8.107435 & -0.437304 & -7.039052 \\
$\mathrm{H}$ & -8.634316 & -1.872848 & -6.119618 \\
$\mathrm{H}$ & -9.045032 & -1.715664 & -7.844343 \\
$\mathrm{~S}$ & -1.125817 & -4.932303 & -6.755847 \\
$\mathrm{C}$ & -2.957793 & -4.826321 & -7.155140 \\
$\mathrm{H}$ & -3.174560 & -3.924500 & -7.732398 \\
$\mathrm{H}$ & -3.549491 & -4.813954 & -6.235400 \\
$\mathrm{H}$ & -3.232264 & -5.703893 & -7.745264 \\
$\mathrm{~S}$ & 5.361921 & -3.908753 & -7.470347 \\
$\mathrm{C}$ & 5.354679 & -5.776240 & -7.253512 \\
$\mathrm{H}$ & 4.341597 & -6.173564 & -7.349513 \\
$\mathrm{H}$ & 5.762217 & -6.051862 & -6.277629 \\
$\mathrm{H}$ & 5.980924 & -6.212288 & -8.035858 \\
$\mathrm{~S}$ & 6.908587 & -6.228567 & -3.435848 \\
$\mathrm{C}$ & 8.099381 & -6.244260 & -1.982078 \\
$\mathrm{H}$ & 7.576196 & -6.493309 & -1.055715 \\
$\mathrm{~S}$ & -4.227385 & 3.736812 & -6.553782 \\
$\mathrm{C}$ & -3.187135 & 5.263342 & -6.894024 \\
$\mathrm{H}$ & 8.586628 & -5.272461 & -1.872916 \\
$\mathrm{H}$ & 8.860845 & -7.004363 & -2.173154 \\
$\mathrm{C}$ & 4.769244 & 2.081175 & -6.526894 \\
$\mathrm{H}$ & 4.521567 & 0.472234 & -7.106781 \\
\hline & -0.001485 & -7.868703 \\
\hline
\end{tabular}




$\begin{array}{llll}\mathrm{H} & -2.358467 & 5.024073 & -7.564147 \\ \mathrm{H} & -2.787718 & 5.669299 & -5.960603 \\ \mathrm{H} & -3.824239 & 6.014771 & -7.366693 \\ \mathrm{~S} & 1.197463 & 7.190921 & -7.154326 \\ \mathrm{C} & 2.723315 & 8.133460 & -6.590160 \\ \mathrm{H} & 3.571645 & 7.456707 & -6.464213 \\ \mathrm{H} & 2.529490 & 8.651620 & -5.647599 \\ \mathrm{H} & 2.970018 & 8.871069 & -7.357982 \\ \mathrm{~S} & 8.859554 & -1.700357 & -2.847407 \\ \mathrm{C} & 8.944472 & -2.160170 & -4.669140 \\ \mathrm{H} & 8.890176 & -1.267562 & -5.296768 \\ \mathrm{H} & 8.130745 & -2.839094 & -4.936900 \\ \mathrm{H} & 9.897505 & -2.662938 & -4.851488 \\ \mathrm{~S} & -6.275711 & -6.586675 & -2.710570 \\ \mathrm{C} & -7.061870 & -6.518456 & -4.418132 \\ \mathrm{H} & -6.436276 & -7.030187 & -5.153116 \\ \mathrm{H} & -7.216659 & -5.483454 & -4.733143 \\ \mathrm{H} & -8.031542 & -7.020043 & -4.369103 \\ \mathrm{~S} & -9.262156 & -2.698693 & -3.252190 \\ \mathrm{C} & -9.755514 & -3.794831 & -1.807737 \\ \mathrm{H} & -9.721541 & -3.236329 & -0.869106 \\ \mathrm{H} & -9.094521 & -4.661909 & -1.737248 \\ \mathrm{H} & -10.778767 & -4.139878 & -1.975611 \\ \mathrm{~S} & -3.274488 & 8.937977 & -2.475742 \\ \mathrm{C} & -4.820441 & 9.157261 & -1.431476 \\ \mathrm{H} & -4.648707 & 8.814962 & -0.407676 \\ \mathrm{H} & -6.556738 & 1.108685 & 5.340741 \\ \mathrm{H} & -5.657893 & 8.600835 & -1.859275 \\ \mathrm{H} & -5.074807 & 10.219856 & -1.410824 \\ \mathrm{~S} & 1.833006 & 9.568204 & -2.835544 \\ \mathrm{C} & 1.051414 & 10.533971 & -1.424955 \\ \mathrm{H} & 1.450642 & 10.205072 & -0.462441 \\ \mathrm{H} & -0.034239 & 10.410546 & -1.427031 \\ \mathrm{H} & 1.288722 & 11.591813 & -1.562315 \\ \mathrm{~S} & 3.238125 & -8.015237 & 3.046538 \\ \mathrm{C} & 3.055299 & -7.276005 & 4.766281 \\ \mathrm{H} & 2.017026 & -6.994061 & 4.956530 \\ \mathrm{H} & 3.698537 & -6.400478 & 4.879893 \\ \mathrm{H} & 3.359126 & -8.036581 & 5.489695 \\ \mathrm{~S} & -0.820394 & -5.859527 & 4.602295 \\ \mathrm{C} & -2.443735 & -5.802529 & 5.546811 \\ \mathrm{H} & -3.042627 & -6.688422 & 5.325000 \\ \mathrm{H} & -3.010941 & -4.905655 & 5.286846 \\ \mathrm{H} & -2.213379 & -5.786477 & 6.614775 \\ \mathrm{H} & -6.770976 & 5.364239 & 3.451686 \\ \mathrm{H} & -5.720649 & 4.353675 \\ \mathrm{H} & -5.517701 & 3.663892 \\ \mathrm{H} & 6.318373 & 4.833158 \\ \mathrm{H} & -1505 & 5.431128\end{array}$




\begin{tabular}{|c|c|c|c|}
\hline $\mathrm{H}$ & -7.042364 & 1.006896 & 6.314081 \\
\hline & 4.551658 & 6.818401 & 3.742449 \\
\hline & 4.189217 & 5.912617 & 5.349172 \\
\hline & 4.622118 & 4.909862 & 5.337687 \\
\hline & 3.111647 & 5.842454 & 5.519834 \\
\hline -1 & 4.635866 & 6.489226 & 6.162943 \\
\hline & 5.649194 & 2.269412 & 4.627425 \\
\hline C & 5.942427 & 0.665280 & 5.558554 \\
\hline $\mathrm{H}$ & 6.854852 & 0.175998 & 5.211344 \\
\hline & 5.092396 & -0.009765 & 5.429268 \\
\hline & 6.047069 & 0.903157 & 6.619726 \\
\hline & 0.012113 & 2.438207 & 7.935611 \\
\hline & 1.793329 & 2.973997 & 8.213638 \\
\hline & 1.990068 & 3.933557 & 7.729298 \\
\hline & 2.486199 & 2.223277 & 6104 \\
\hline - & 1.952823 & 3.081355 & 9335 \\
\hline 5 & 2.879171 & -1.485320 & 90025 \\
\hline C & 1.323588 & -2.016064 & 8.500630 \\
\hline $\mathrm{H}$ & 0.903698 & -2.922765 & 8.058742 \\
\hline $\mathrm{H}$ & 0.572817 & -1.223189 & 8.476305 \\
\hline П & 1.589401 & -2.220814 & 9.540803 \\
\hline S & -3.013311 & -1.349726 & 7.939505 \\
\hline C & -3.454773 & 0.43 & 6751 \\
\hline 7 & -4.292421 & 0.770675 & 9430 \\
\hline $\mathrm{H}$ & -2.594591 & 1.090432 & 9279 \\
\hline $\mathrm{H}$ & -3.746220 & 9191 & 8368 \\
\hline $\mathrm{H}$ & 5.689876 & -5.251492 & 0.720707 \\
\hline $\mathrm{H}$ & 5.278451 & -2.242361 & 4.346580 \\
\hline $\mathrm{H}$ & 3.222600 & 1.749592 & 4.333630 \\
\hline $\mathrm{H}$ & -0.370377 & -3.558068 & 4.344815 \\
\hline $\mathrm{H}$ & -5.720077 & -1.761624 & 4.189259 \\
\hline $\mathrm{H}$ & -3.387739 & 1.879017 & 4.566119 \\
\hline $\mathrm{H}$ & -4.707662 & -6.032930 & 1.397120 \\
\hline $\mathrm{H}$ & -7.542577 & -2.411042 & 0.704750 \\
\hline $\mathrm{H}$ & -7.479866 & 1.208659 & -4.010001 \\
\hline $\mathrm{H}$ & -4.877996 & 4.554491 & -4.385407 \\
\hline $\mathrm{H}$ & -3.076983 & 7.153761 & 1.082592 \\
\hline $\mathrm{H}$ & 0.999330 & 5.470927 & 4.513914 \\
\hline $\mathrm{H}$ & 1.536493 & 7.861600 & 1.262886 \\
\hline $\mathrm{H}$ & 4.242060 & 6.038282 & -3.934130 \\
\hline $\mathrm{H}$ & 5.852533 & 2.117570 & -4.490571 \\
\hline $\mathrm{H}$ & 7.357478 & -1.085914 & 0.999245 \\
\hline $\mathrm{H}$ & 2.663526 & -6.385851 & -4.535174 \\
\hline $\mathrm{H}$ & -1.442387 & -6.053192 & -4.663869 \\
\hline $\mathrm{H}$ & -2.527855 & -0.670750 & -7.943944 \\
\hline $\mathrm{H}$ & 1.931427 & -1.275325 & -7.919124 \\
\hline $\mathrm{H}$ & 0.149068 & 3.118624 & -7.707261 \\
\hline
\end{tabular}

